\title{
Lumen
}

Selected Proceedings from the Canadian Society for Eighteenth-Century Studies

\section{'An Entire Change of Performances?' The Politicisation of Theatre and the Theatricalisation of Politics in the mid 1790s}

\section{John Barrell}

Volume 17, 1998

Theatre of the world

Théâtre du monde

URI : https://id.erudit.org/iderudit/1012379ar

DOI : https://doi.org/10.7202/1012379ar

Aller au sommaire du numéro

Éditeur(s)

Canadian Society for Eighteenth-Century Studies / Société canadienne d'étude du dix-huitième siècle

ISSN

1209-3696 (imprimé)

1927-8284 (numérique)

Découvrir la revue

Citer cet article

Barrell, J. (1998). 'An Entire Change of Performances?' The Politicisation of

Theatre and the Theatricalisation of Politics in the mid 1790s. Lumen, 17, 11-50.

https://doi.org/10.7202/1012379ar

Copyright (C Canadian Society for Eighteenth-Century Studies / Sociéte canadienne d'étude du dix-huitième siècle, 1998
Ce document est protégé par la loi sur le droit d'auteur. L'utilisation des services d'Érudit (y compris la reproduction) est assujettie à sa politique d'utilisation que vous pouvez consulter en ligne.

https://apropos.erudit.org/fr/usagers/politique-dutilisation/ 


\section{2. 'An Entire Change of Performances?' The Politicisation of Theatre and the Theatricalisation of Politics in the mid 1790s}

The Reverend Vicesimus Knox, now remembered if at all as the editor of Elegant Extracts and author of Essays Moral and Literary, was a staunch Whig whose political views in the mid 1790s verged on republicanism. In August 1793, on holiday with his family in Brighton, he preached a sermon at the parish church on the unlawfulness of offensive war, and, by implication, of the war against the French republic. A day or so later, to cries of 'Out with the Democrat,' he and his family were driven from the Brighton Theatre by some enraged officers of the Surrey militia. In March of 1794 a Mr Curtis, attending the theatre at King's Lynn in Norfolk with his family and friends, was assaulted by some 'military heroes,' as he styles them in a pamphlet describing the incident. He had refused to stand or pull off his hat when what he calls 'that musical, mouthful of mockery, "God save the King"' was being played. To Curtis the song was doubly impious, both an encouragement to idolatry and an attempt to persuade God to enlist on the British side in what he, like Knox, evidently regarded as a war of aggression. He was assaulted by some officers of the Nottinghamshire militia, and something like a riot followed; a man was stabbed, and two ladies were thrown into violent hysterics. The next night Curtis returned to the theatre, armed with a stick, supported by friends, and determined on a repeat performance. To provoke the inevitable confrontation, the militia instructed the players to sing the national anthem. Curtis was hissed by the militia, and another riot ensued, but he managed to give his second performance, remaining seated, his head covered, while the battle raged around him. ${ }^{2}$

A month later a similar but more serious affray broke out in the theatre at Edinburgh, during a performance of a play about Charles I, whose fate could not help recalling, in the years after 1793, and was frequently evoked to recall, that of Louis XVI. The story is recounted in a letter by 
David Downie, an elderly radical goldsmith, who in September of 1794 would be found guilty of High Treason for his part in a conspiracy to seize Edinburgh Castle. 'The play began,' writes Downie,

when some furious Aristocrats, wanting, no doubt, to try the disposition of the people, called out for the tune of God save the king. The tune was just beginning, when an universal hiss, mixed with lamentable murmurs, pervaded all over the house; and the sons of the fiddle were obliged to desist ... The discomfited Aristocrats ... in order to effect their purpose, called in the Fencibles in the Castle, with their officers, and then desired the royal song to be again attempted, when, meeting with the same treatment as before, the officers drew their swords, and the soldiers their instruments of death ... and these heroes went to such a length, as to cut and maim several people in the pit, who refused to take off their hats as the tune was going on ... After the tune was over, the play went on as if nothing had happened. ${ }^{3}$

These stories - and there are more which I have not mentioned ${ }^{4}-$ are about all sorts of things. They are about the tensions created, in the mid-1790s, by the stationing of an ultra-loyalist militia army in towns and cities where they had no local attachment, and in a country still with a long tradition of hostility to keeping standing armies at home. They are about how, immediately before and during the war with the French republic, the national anthem became an object of fierce contest, one which produced a long series of parodies of the song, as 'God save "THE RIGHTS OF MAN!",' as 'God save great Jolter-Head,' as a hymn to the guillotine, as a prediction of the execution of George III and the Prime Minister William Pitt, as a hymn to the French Revolution, as a satire on the extravagance of the Prince of Wales, as a celebration of the Duke of York's inglorious retreat, and so on. ${ }^{5}$ Most of all, however, these stories are about the theatre as a new kind of public space, where the spectators come to display not only their clothes, their social connections, their fashionable taste, their sensibility, but their political commitment. In a period in which every area of life was becoming politicised, they are about the theatre as a site of political confrontation; about attempts on both sides to appropriate it as a loyalist or radical political space, in which at any time the audience, rather than the managers, the authors, the cast, may become the chief objects of attention.

In the 1790 s the theatre was the only place of public resort, with the arguable exceptions of the law courts and Parliament itself, where confrontations between loyalists and reformers could be staged in public. The decencies of respectable behaviour, and the political division between church and chapel, prevent such confrontations happening in places of public worship: it is precisely to the point that those Knox 
offended in church chose to wait to exact their revenge in the theatre. There are numerous stories of such confrontations in public houses, among the artisan and labourer classes, and in coffee-houses, among the middle class; but they are played out before a tiny audience, and those which left a trace did so only when, months later, they resulted in prosecutions.

\section{II}

The most celebrated, or, according to your politics, the most notorious of radical attempts to stage such a confrontation in the theatre, and to appropriate the theatre for the cause of radicalism, was the campaign launched at the Covent Garden Theatre in February 1794 against Thomas Otway's tragedy Venice Preserv'd. The instigator of this campaign was the poet and orator John Thelwall, who in the following December would be acquitted of High Treason, in the last of the three trials in which Thomas Hardy, secretary of the London Corresponding Society (LCS), and John Horne Tooke, of the Society for Constitutional Information, had already been acquitted. As Thelwall later put it, Otway's play had been written 'with the view of paying his court to Charles II., and for the purpose of bringing detestation upon the patriots of those times, by representing all reformers as conspirators. ${ }^{6}$ Thelwall, however, regarded it as a play which, whatever its official political tendency, could be stolen from the loyalist repertoire, and represented as part of a radical canon which he, together with booksellers like Daniel Isaac Eaton and Thomas Spence, was involved both in forming and in popularising; for the play contained dialogues and speeches, spoken by the conspirators, which could be read as a critique of the corruption of government, and were expressed in the language of classical republican virtue which the English radicals were claiming as their own. At the first night of the Covent Garden production, Thelwall and his friends duly applauded and encored what they regarded as the 'republican' passages, and after one more performance the play was regarded as too politically embarrassing and was taken off. ${ }^{7}$

The play however would not go away. The dialogue Thelwall most admired was reprinted and circulated as a handbill. ${ }^{8}$ In October 1795 the dramatist and Whig M.P. Richard Brinsley Sheridan provocatively staged an elaborate new production of Venice Preserv'd at Drury Lane. The third night of this production fell on the day when the king's coach was attacked by an angry crowd as he was on his way to open the new session of Parliament; a missile of some kind nearly hit the king, and the king himself, and the newspapers funded by the government, treated 
this as a full-blown assassination attempt. The government used the incident as a pretext to introduce new laws designed finally to silence the movement for reform, in part by creating a series of new treasons which, had they been in place a year earlier, would have made the conviction of Hardy, Tooke and Thelwall all but certain. At Drury Lane, following Thelwall's example if not with his participation, the speeches of Otway's conspirators were greeted in the same manner as in the previous year, and the following day, much to the satisfaction of the government press, the play was withdrawn. The success of the campaign against Otway's tragedy can be measured by the fact that, when it began, Otway's tragedy was still widely regarded as a loyalist play, and Thelwall's appropriation of it as a misappropriation. When the attempt was repeated, however, in October 1795, the ministerial press turned on the play itself, as if it were unequivocally the dangerous work that Thelwall had tried to make it. The True Briton, a newspaper largely funded by the Treasury, spoke of its 'obscene and objectionable passages, so disgusting to a modest, so unpleasant to a loyal ear'; 'passages,' it continued, 'which make all honest men shudder!" Thelwall summed up the story by remarking that 'the play ... notwithstanding its original intention, was ... converted into a provocative, not an antidote to jacobinism,' by the tactic of loudly applauding and calling attention to what he described as its 'popular sentences.' 10

Loyalist newspapers had at first represented the production merely as ill-judged and ill-timed, but a few days after the attack on the coach they began to treat it as an essential part of a republican plot. The aim of the production, the Times announced, had been to prepare the minds of those who had attempted to kill the king by inflaming their passions and inspiring them with a 'thirst for blood. ${ }^{11}$ But the Times can hardly have imagined that those who had applauded the objectionable passages were the same people as allegedly attempted to kill the king. 1795 was a year of near famine; many of the crowd who mobbed and later destroyed the king's coach were carrying loaves of bread stuck on poles and swathed in black crepe; their cries were for bread and for peace with France, for the war was widely blamed for a huge rise in the cost of food. However much more broadly based the audience at the theatres was becoming, it certainly did not include the very poor. The Times's claim, if it makes sense at all, does so only in terms of the publicity which would be attracted by a demonstration in the theatre, and which could be attracted to that degree nowhere else. The point of the demonstration was to generate news, as a means of influencing the passions of those who never attended the theatre, at least the polite theatre, at all. Whether or not the Times is right about this, it is pointing to something about 
Thelwall's campaign which separates it from the theatrical incidents in the provinces that I glanced at earlier.

The point of that campaign, and its success, depended upon two circumstances which were unique to London. The first is that the London theatre was of national interest, and the London newspapers were increasingly becoming national newspapers. One of the most characteristic features of the London newspapers of the period was the remarkable number of column inches given over to advertisements for plays, to reviews of plays, to news about plays in production and the private lives of the leading players. News about the London theatres would be read all over the country, either in the London newspapers themselves or in provincial papers which reprinted their reports. Secondly, in London there were newspapers of very different political complexions from extreme loyalist to extreme reformist. The useful contrast here is with Edinburgh, which at the end of 1793 had lost its only reformist newspaper, the Edinburgh Gazetteer; thereafter what was news in Edinburgh was what the loyalist papers chose to regard as fit to print. No newspaper there, according to David Downie, chose to mention the riot at the performance of Charles I; indeed the whole point of his letter, written at a time when he was actively attempting to revive the Gazetteer, ${ }^{12}$ was that his correspondent in Perth would hear of the riot by no other means. The variety of the London press meant that stories there could not be killed in the same way; and there could hardly have been a more certain means of generating a story about politics than to stage a political confrontation in a London theatre. In contrast with those apparently more spontaneous confrontations elsewhere, the appropriation of Otway at Covent Garden and Drury Lane were media events, performances staged for the newspapers, as much examples of the theatricalisation of politics as of the politicisation of theatre.

\section{III}

We can get an oblique sense of the symbiotic relation of the London theatre and the London press, and a further sense of how loyalism regarded the attempts of reformers to create a theatrical culture friendly to democracy, from a superb satire in the Times, published on September 61794 , just over a month before the London treason trials were scheduled to begin, and with the evident intention of prejudging the defendants. ${ }^{13}$ The satire is of the Times itself as it would be in 1800, in the 'First Year of the Republic One and Indivisible,' when the reformers had finally achieved the democratic and republican revolution they were imagined to desire. Beneath a new logo, no longer the clock and scythe but the 
guillotine, the reports and advertisements in the New Times reveal that in 1800 a National Convention has replaced Parliament, and that equality of property, or its destruction, for they come to the same thing, has become, despite the earlier denials of the reformers, the main programme of Britain's new rulers. These include many of those who in 1794 had been awaiting trial for High Treason. Hardy and Thelwall have cheated the hangman; Hardy is now President of the Committee for the Sale of the Effects of the Nobility, Thelwall President of the British National Convention. Horne Tooke may have been less fortunate, but his name is remembered in Horne Tooke Square, formerly Grosvenor Square, and Horne Tooke Street, formerly St. James's Street. His place in the new political and cultural élite, and those of other unmentioned absentees who were due for trial in 1794, has been filled with repatriated radical exiles from France, America or Botany Bay.

Whether because or in spite of the efforts of these and other heroes of the revolution, the new republic is in a state of economic ruin, surviving only by confiscations and forced loans, and awash with worthless paper money. The New Times itself costs 'one shilling in specie,' or 'five shillings in paper;' English banknotes have no price at all in any foreign currency except French assignats; East India stock is worthless. Leather being unobtainable, shoes are now made of wood; experiments are being conducted into the feasibility of making bread from bones. Civil war rages in the provinces, and a royalist army in Devon has completely defeated the army of the new republic. The main news item is a report of the latest 'sitting' of the British National Convention to consider reports on the successful plunder and demolition of aristocratic houses. Forthcoming debates include one on 'the more regular operation of the Holy Guillotine.' In the advertisement column, a female citizen, 'Honora Goodwill,' apparently modelled on Mary Wollstonecraft, advertises her new school, where young ladies will learn atheism and 'the principles of pure Republicanism,' and 'will in a short time acquire that Republican energy, so preferable to the silly timidity, which was one of the female characteristics during the reign of despotism.' They will also, it is hinted, be taught the theory and practice of promiscuity, for Miss Goodwill whose name seems to suggest she is anything but jealous of her honour - promises that they will be guided by 'Nature's laws alone.'

But if morale in the new republic is low, it would be lower still but for the efforts of Joseph Priestley and Jeremiah Joyce, the latter one of those charged with High Treason along with Thelwall, but acquitted when the Crown offered no evidence against him. There is a programme of civic pageantry: Citizen Joyce is now 'Minister of the NATIONAL CHURCH,' and about to 'celebrate in the Temple of Reason (ci-devant ST. PAUL'S $\mathrm{CHURCH})$ a jacobin festival for the happy destruction of the Parlia- 
ment.' Citizen Priestley has returned from America, his task to instil a spirit of civism in the British, by dramatic exhibitions at the Theatre of Equality. Priestley's current playbill advertises an opera, 'The Mitre in Jeopardy; or, the Triumph of Civism over Religion,' and a ballet, 'The March of the Clergy to Bedlam,' with an all-star cast: Thomas Paine plays the Archbishop of Canterbury, and the Archbishops of York, London and Durham are all played by notorious radicals either returned from Australia or released from Newgate. The Irish nationalist and revolutionary, Citizen Archibald Hamilton Rowan, performs opposite 'the Female Citizen Deism,' in a pantomime entitled 'Sedition.' Seats are wildly expensive, except for those able to pay in coin. Small beer and gin are available in the interval. The audience is advised to observe a strict code of dress: bonnets rouges are compulsory, clean shirts preferred; all boots must be scraped at the door.

Meanwhile the patriotism of the less sophisticated is fostered at the Theatre of the Sans Culottes in Wapping, where revolutionary airs are played on the salt-box and the marrowbone and cleaver, the instruments of rough music everywhere associated in the late eighteenth century with the 'Wapping Concert.' A new play is in production, 'The Chimney-Sweeper's Apotheosis, or, Dress no Ornament to Republicans.' A review of this piece acknowledges that the acting is sub-standard, as compared with the golden days of Covent Garden, for the great entertainers of pre-revolutionary times have all been executed for persisting in singing the national anthem at the end of their performances. But as the reviewer observes, 'we cannot eat our cake, and have it too': we can have revolution, or we can have great theatre; 'real Republicans,' he advises, had better know which to prefer.

\section{IV}

The theatrical references in the New Times may perhaps be read as a riposte to a new and immensely inventive form of radical propaganda, the mock advertisement, which represented the activities of George III and the government of Pitt as series of spectacles and entertainments ceremonial processions, exhibitions of paintings, ${ }^{14}$ and so on, but primarily plays and magic-shows. These satires emerged early in 1794, were immediately suppressed by the government, and then re-emerged again in November 1794, following the acquittals of Hardy and Horne Tooke. Thereafter, they appeared in considerable numbers, and became one of the most popular forms of radical satire on the king and the government, until they were suppressed again at the end of 1795 , by the exemplary arrest of one of the booksellers who published and sold them, and by the 
passing of the Treasonable Practices Bill, which made a second offence of publishing a seditious libel punishable by transportation. These satires raise all kinds of fascinating questions - about how they were disseminated, their authorship, their supposed audience, the effect they were intended to have, the relations between aristocratic and middleclass reformers and the popular radical movement, and so on. They also raise a very specific question about the policy of the government, which, having suppressed the first examples when they began to appear, allowed them to proliferate unchecked for most of 1795 .

The first of these radical mock-advertisements was discovered in York, and its supposed publisher, a leading Yorkshire reformer, was swiftly prosecuted and imprisoned. ${ }^{15}$ But a week or so later the advertisement appeared at a meeting of the LCS, and it almost certainly originated in London, as did every subsequent example of the genre. ${ }^{16}$ Later in the year the advertisement was produced at Thelwall's trial, once again as evidence of his treasonable disposition. When in May 1794 the leaders of the London reforming societies were rounded up, another such advertisement was discovered, 'La Guillotine; or, George's Head in the Basket' (fig. 1): so effectively was this suppressed that no original copy is known to have survived, and we know of its contents only because it was produced in evidence at the trial of Hardy, and so appears in the transcript of the trial. According to the spy George Lynam, who had infiltrated the LCS and gave evidence at the trial, the advertisement had been written by a 'gentleman' from Walworth named Cruden, who was rich enough to keep his own phaeton, and was possibly himself a member of the LCS. ${ }^{17}$ The parliamentary committee responsible for assembling the evidence against the reforming societies was particularly alarmed by these advertisements, which they regarded as an especially effective way of bringing the government into contempt, and as designed, in the committee's words, 'to render deliberate incitements to every species of treason familiar to the minds of the people. ${ }^{.18}$ In the mass interrogations that preceded the treason trials, prisoner after prisoner was asked if they had seen them, who had printed them, who had circulated them. Nothing conclusive was discovered. ${ }^{19}$

The pasquinade advertising 'George's Head in the Basket' is more accessible than most of these mock-advertisements, less dependent than others on the topical allusions which make it difficult to explain the point of their jokes except at the kind of length which would make them seem more laboured than amusing. The playbill advertises a performance, on All Fool's Day 1794, in Federation Square, named in honour of the imagined union of the new republics of Britain and France. Here all the male members of the royal family will be executed, together with the Prime Minister and a handful of leading loyalists. Edmund Burke is on 
the hit-list, for his tireless condemnation of the revolution in France; so is John Reeves, founder in late 1792 of the Crown and Anchor Association, designed to facilitate the prosecution of seditious publications and seditious utterances; so is the Duke of Richmond, the proponent in 1780 of a plan for the introduction of universal manhood suffrage which had become the manifesto of the reforming societies, but now a member of Pitt's Cabinet and a dedicated opponent of reform. Among those imagined as waiting in line for their turn to be sacrificed are the European monarchs confederated against the French republic, including Britain's future ally, Catherine the Great, and the Prince of Hesse-Cassel, who profited by leasing his subjects to fight as mercenaries in the armies of the allies.

These recreants will all be in the custody of 'municipal guards,' like those who had attended the guillotining of Louis XVI; these guards, however, are members of the parliamentary opposition to Pitt's government, Charles James Fox and his more reformist colleagues, Sheridan, Charles Grey, who had moved an unsuccessful motion for parliamentary reform in 1793, and would later introduce the 1832 Reform Act, and Thomas Erskine, who would soon act as defence counsel for Hardy, Tooke and Thelwall, and to whose advocacy their acquittal would be widely attributed. Entertainment will be provided by the Duke of Brunswick, who had issued the notorious manifesto against the French, and by the leading bishops of the Church of England, who will exhibit their skills at rope-dancing - the kicks and involuntary contortions of the hanged. The chorus will sing one of the unofficial anthems of the French republic, and yet another republican version of the national anthem of Britain, which now implores God not to save but to shave - to guillotine - the king. The entertainment is to be concluded by a mass guillotining of those who benefit from government corruption. Admission to the theatre is very competitively priced, to allow the attendance of the very poor. Genuine playbills frequently ended with the patriotic wish, Vivant Rex et Regina; this one ends with an appropriately republican wish, not in Latin but in the language of liberty.

\section{V}

Over a dozen of the radical leaders in London were charged with High Treason, but after the first three trials all resulted in acquittals, the government, to its enormous embarrassment, was forced to abandon the attempt to use the law of treason to suppress the radical movement. It was now that the floodgates opened, and a long series of mock-advertisements began to be published. Almost all of them first appeared in 
radical newspapers such as the Courier and the Telegraph, but were then reprinted and sold at a penny each as single sheets, in form exactly like genuine play-bills and advertisements for other public entertainments, and with inventive typographical variation which brilliantly parodied the hyperbole of genuine advertisements. The first mock-advertisement discovered in 1794 was small in format - smaller than an A4 sheet, and modelled on advertising handbills passed out in the street, though I doubt if anyone would have been foolhardy enough to circulate it that way. 'George's Head in the Basket,' however, appeared first as a handbill and was later reprinted as a broadside, twice the size. ${ }^{20}$ The post-trial advertisements were almost all printed as broadsides. Though we have no record of quite how they were used, it seems likely that they were deliberately collected, as Spence's political tokens were. ${ }^{21}$ We know too that some radical propaganda was circulated by bill-stickers, ${ }^{22}$ and it is likely that these broadsides were clandestinely pasted up in the street alongside genuine advertisements, from which, at a distance, they would have been indistinguishable. Indeed, Wordsworth's account of street-advertising in the London of the 1790s may suggest as much. He writes of 'ballads' and 'Advertisements of giant size' pasted to 'dead walls' - walls without doors or windows - below which, one 'fronted with a most imposing word, / Is peradventure one in masquerade. ${ }^{23}$ The editors of the Norton Prelude suggest that, unlike the other bills, this one is 'in masquerade' because it 'disguised the true nature of the goods on sale.' It seems rather more likely to me that it was one of these mock-advertisements Wordsworth had in mind: he was living in Lincoln's Inn in early 1795, in the months when almost all the bills I am discussing were produced. ${ }^{24}$ To paste such spurious bills among the genuine would have reinforced the primary message of many of them, that the activities of the king and his government - state occasions like the opening of Parliament - were no more or less than spectacles or illusions, designed at once to distract the public from the urgency of the continuing political crisis, and to dazzle them into political subjection.

The first group of post-trial advertisements was directed primarily against Pitt. The huge and humourless authority with which Pitt spoke in Parliament, and his freedom from every private vice except bibulousness, had made it difficult before the London treason trials for radical and opposition writers to find in him the kind of weakness that gives a handle for satire. The acquittals, however, provided two. Pitt gave evidence at Tooke's trial, and his reluctant and shifty testimony - he pretended to have forgotten his own earlier activities in favour of parliamentary reform - had put in question, or so it could also be pretended, the reliability of his memory. ${ }^{25}$ Throughout the thirteen months following Tooke's acquittal, the amnesia which had so suddenly afflicted 
him became the most frequent topic in satires of Pitt, and so ensured that he would never be allowed to forget what he could not remember. ${ }^{26}$ Secondly, the acquittals allowed the alarmism that Pitt had carefully nurtured since the Royal Proclamation of May 1792 launched the prosecution of Paine, but which had arguably now been declared by three juries to have no rational basis, to be treated as an object of mirth as well as of anger. There had been no revolutionary plot: Pitt and his friends had been imagining things.

Following the acquittal of Tooke, a series of pasquinades began to appear which satirised Pitt as a professional magician, Signor Gulielmo Pittachio, who boasts that he is a master of illusion in advertisements that reveal him to be a mere illusionist, whose most successful trick is to bribe his audience to pretend they cannot see through his tricks. The first of the series originally appeared in the radical newspaper the Courier on November 28 1794; it reappeared as a handbill, and finally emerged as a broadside, the first to exploit the typographical variety and excitement of street advertising. ${ }^{27}$ The Pittachio pasquinades, all of which announce him as performing at the theatre in Westminster - the House of Commons - were closely modelled on genuine advertisements for magic shows, of which dozens survive ${ }^{28}$ for these shows were immensely popular, given by men whose names, exotic in a British context, were no doubt intended to guarantee the uncanny nature of their illusions: Henry Breslaw, Mons. Boulevard, Highman Palatine, Katerfelto, Sieur Hermon Boaz, Sieurs Rea, Sen. and Jun., Sieur Cosmopolitan, Sieur Connus, Signor Zucker, and so on. Pittachio, however, was modelled on the celebrated Italian illusionist Signior Guiseppi Pinetti, who had made his name in pre-revolutionary Paris, and had performed in England at least since the mid 1780s (fig. 2). The idea of comparing Pitt with Pinetti had been first developed in an elaborate 'Parallel' between the two men in the Political Miscellanies which in the late 1780 s came to be attached to the anonymous collection of anti-Pitt satires in The Rolliad; this had anticipated a number of the best jokes in the first two Pittachio pasquinades. ${ }^{29}$ According to an anonymous contemporary epigram, Pinetti excelled all his rivals in the brazenness of his performance and of his advertising:

Three sons of magic in the same age born,

Prussia, England, Italy adorn.

The first has in the lofty puff surpas'd,

The next in insolence - in both the last.

Since human patience can no farther go,

Hang up the last, to scare the former two. ${ }^{30}$ 
One such showman advertised his slides under the title "THE POWERS OF IMAGINATION; OR, THE SENSES DECEIVED' $;^{31}$ and one of the most repeated complaints about Pitt's alarmism was that it was an attempt to 'bewilder the imagination,' to persuade the people, against the evidence of their own senses, that reformers were revolutionaries. Pitt's ability to convince his parliamentary supporters that seeing was not believing was partly the effect, so the first Pittachio pasquinade announced, of bribery; of magic gold dust, which produced 'a most extraordinary effect in the optics of Spectators ... so that they shall not be able to distinguish colours; but shall call (at the Signior's command,) BLACK, WHITE, AND WHITE BLACK, to the edification of all beholders' (fig. 3). The readiness with which the spies of government attempted to pass off patriots as traitors was the effect, the advertisement explained, of Pittachio's 'justly celebrated, CURIOUS SPY GLASSES, which distort and misrepresent all objects that are looked at through them, and occasion in the company A SUDDEN AND SOCIAL DISMAY.' To ensure the success of these and other attempts to bewilder the imagination 'to give greater effect to the DECEPTIONS' - the audience at the show was to be kept 'as much in the dark as possible. ${ }^{32}$

Pittachio's performance is announced as beginning with the ringing of 'a magical alarm bell, at which all the company shall become mad or foolish.' A magic bell was a feature of a number of magic shows. A $\mathrm{Mr}$ Lowe, for example, performed a trick with a 'Miraculous Bell.' '[The] Wonderful Bell,' he claims, 'is placed on the Table before all the Company, and Mr. LOWE commands it to strike, without being touched, (also desired by any Person in the Room. - The same Bell will answer to several Questions, and also to strike the Number thought [of] by any Person present).' Lowe's act also contained 'A Wonderful Automaton Figure,' which, he promised, 'will appear on the table, pay his Respects to all the Company, then instantly vanish out of Sight. The same Figure will appear, and disappear, Twenty Times, if desired. ${ }^{33}$ Pittachio too uses automata: in a satire of Pitt's management of his parliamentary majority, his act is said to include 'UPWARDS OF TWO HUNDRED AUTOMATA, OR MOVING PUPPETS, Who will rise up, sit down, say Yes, or No, Receive Money, Rake among the Cinders, or do any Dirty Work he may think proper to put them to. ${ }^{34}$ In early editions of this advertisement, Pittachio ended by apologising that he had been disappointed in his attempts to engage the rope-dancers he hoped to have exhibited, the leaders of the radical societies; but as they had escaped conviction, 'This Part of the Entertainment must therefore be deferred.' In the final edition, Pittachio announces that his grand finale will now be supplied, to the delight of the Swinish Multitude - the people, in 
Edmund Burke's notorious description of them - by an exhibition of himself on the tight-rope.

In the second - the briefest and funniest - Pittachio pasquinade (fig. 4 ), the sublime magician responds to a rumour that the opening of Parliament would be delayed while the government considered how to manage the debacle of the treason trials. ${ }^{35} \mathrm{He}$ will certainly re-open Parliament soon - if he remembers to. Pinetti sometimes included in his advertisements a list of his international honours and distinctions: 'Professor of Mathematics and Natural Philosophy; Knight of the Order of Merit of St. Philip, pensioner of the Court of Prussia, Aggregate to the Academy of Sciences and Belles Lettres of Bordeaux, and Natural Philosopher to the Court of France. ${ }^{36}$ This second pasquinade contains a similar list of Pitt's 'honourable distinctions,' among them 'Winum guzzleando potentissimus,' alluding to Pitt's fondness for drink, and 'Prettygirlibus indifferentissimus,' alluding to his entire lack of interest in sexexcept perhaps the solitary sex he offers to perform on stage at the end of the first Pittachio pasquinade. According to radical black propaganda he was equipped with only vestigial or atrophied genitals. ${ }^{37}$

By the third of the series (fig. 5), first published in Telegraph on January 29 1795, and issued soon after as a broadside, ${ }^{38}$ Pittachio has become a more varied entertainer, and a general impresario; his show now includes, among other things, a wider range of deceptions and other turns which related directly to the trials: his 'INESTIMABLE FANTOCCINI,' who 'could pronounce the Words, WAR, TREASON, MURDER, and other popular expressions, AS IF THEY WERE LIVE CHRISTIANS'; 'a Humorous Dialogue between JACK KETCH, and a CROWN LAWYER, on the subject HIGH TREASON'; and a 'Serio-Comico-Dramatico Medley' in which the performers included the three heroes of the 1794 trials: 'Mr. Hardleather,' Mr. Horner, Mr. Telwell.' The continuing emphasis, however, was on Pittachio's ability (or what he believed to be his ability) to bewilder the imagination by persuading people to ignore the evidence of their senses: "The PITTACHIO ... will also so alarm them by his skill in the occult Arts, That he shall take them up, knock them down, handcuff them, rummage their pockets, and read their letters, with the most captivating decorum, and to their perfect Satisfaction. ${ }^{39}$

Pittachio starred in at least three more mock advertisements, ${ }^{40}$ and, as we shall see, he made guest appearances in pasquinades mainly directed at other politicians. He also gave birth to a number of imitators. In February 1795 the Morning Post re-invented him as 'Signor Pito,' the hero of 'a Serious English opera, call'd THE CAMPAIGN.$^{41}$ In another broadside of the same month, 'Pittpatche' announced the government's plans to take revenge on the members of the reforming societies who had escaped him at the trials, by forcibly enlisting into the army 'all Jacobins, 
Republicans, and Reformers,' and thus making them 'SLAVES without injuring their Feelings as FREEMEN. ${ }^{42}$ There was 'the Sublime Sultan Pittander Omnipotent,' an oriental despot who is comforted on the outcome of the trials and the failures of war by his adoring subject Mustapha, in tones of abject humility, and in a form and language derived from the Song of Songs. ${ }^{43}$

By mid-February 1795 Pittachio had served his turn, and the mock-advertisements began to look for other targets. Thus Harlequin Impeacher (fig. 6), for example, is aimed principally at Edmund Burke: ${ }^{44}$ Harlequin because he was a turncoat (the most eloquent British supporter of the American Revolution, the most furious enemy of the French); impeacher because he had led the long impeachment of Warren Hastings, which finally ended with Hastings's acquittal in April 1795, when this broadside probably appeared. Like several of the other broadsides, this one glances at a real play, Harlequin Dr Faustus; or, The Devil will have his Own, which, in its latest version, had been presented at Covent Garden in December 1793, and had been advertised by an elaborate playbill which, like this one, gave lengthy details about the contents of every scene. ${ }^{45}$ The plot of Harlequin Impeacher is based on the plot which, radicals believed, had been concerted in the monarchies of Europe against the revolution: in the radical reading of the history of the early 1790 s, Burke, by mobilising European opinion against the revolution in his Reflections, bore the main responsibility for the aggressive war against France, and for the jacobin terror; the Faustus who in scene five makes Robespierre 'Prime Minister of France' is no doubt intended to be Burke.

The main target of Grand Exhibition at Wimbledon!!! (fig. 7) ${ }^{46}$ is Pitt's favoured drinking companion, the Scot Henry Dundas, who as Home Secretary had coordinated the attack on the radical societies, and in 1795 as Minister for War was seen as equally responsible with Pitt for prolonging what was, at this stage, a markedly unsuccessful war with France. Every year during the war, the king proclaimed a fast day, on which the nation was meant to abstain from food, acknowledge its sins against God, and, thus purified, pray for God's help in the war against France. These fast days were always controversial for suggesting that God would lend a hand in destroying the French republic, which many dissenting radicals regarded as God's chosen agent in his war with the Anti-Christ, the Pope. But the fast day in 1795, the year of scarcity, was particularly controversial: for the poor, argued opponents of the war, every day was now a fast day. ${ }^{47}$ This mock-advertisement tells us how 
the ministers of the government will pass the day: in a grand eating match to be held at Dundas's private residence, to be attended of course by 'the Sublime PITTACHIO,' who is advertised as undertaking to deliver 'a bottle oration' in which his Dutch Courage will persuade him to march the British Army to Paris.

The 1795 fast day led one particularly courageous radical and plebeian publisher, Richard Lee, to reprint the handbill found and prosecuted a year earlier in York, this time in large format, and retitled, in keeping with the threatening famine, Amusement for starving Mechanics (fig. 8). ${ }^{48}$ In this George III is satirised as King Nebuchadnezzar, who, rather like George himself, had suffered from temporary insanity and temporarily lost his throne. On this fast day, not the God of Elijah but Baal, the god worshipped by Church of England bishops and government ministers, would be called upon to smite the armies of the 'Righteous,' the French government and people who were faithfully carrying out God's commands in making war on the Catholic Church. Baal had already been begged, of course, in 1793 and 1794, to 'bless their ARMS, and sanctify their CRIMES,' yet British arms had met with little success. Hitherto, the advertisement explains in the mocking words of Elijah, Baal cannot have heard the prayers of loyalists, 'He being, when before called upon either Talking, or Pursuing, or on a Journey, or peradventure Sleeping, and must (now) be AWAKENED. ${ }^{49}$

Richard, or as he came to call himself, 'Citizen' Lee was a Methodist and millenarian who was twice expelled from the LCS for opposing the increasingly atheist tendency of the society. He became the chief printer and supplier of these mock-advertisements during most of 1795 . His Grand Order of Procession (fig. 9) foresees the glorious celebrations when, on All Fools' Day in some as yet unspecified year, the allies finally enter Paris to establish the boy-king Louis XVII on the throne of his executed father. ${ }^{50}$ The typographical high jinks characteristic of late eighteenthcentury advertising are working wonderfully in this broadside: for example in the discreetly tiny print which hints at Pitt's apostasy from the cause of reform, signified by his 'Superb suit of changeable Silk,' what is now called shot silk; ${ }^{51}$ or in the large-print 'MONARCH' who enters his capital sitting on Pitt's knee, and the contrast thus implied between the enormous task of being absolute monarch of the largest state in Western Europe, and the tiny pretender to the throne, now 11 years old.

Another of Lee's advertisements describes the grand theatrical entertainment to be held when, at last, the revolution has been accomplished in Britain, and the swinish multitude has seized the government from Pitt and the theatres from Pittachio 'and his Fellow Professors in the Black Arts' (fig. 10). ${ }^{52}$ There will now be 'An entire Change of Performances:' the Tower of London will be stormed, St. James's Palace invaded 
by the swinish multitude, the Treasury ransacked. The crown will be magically transformed into a cap of liberty, ministers will be hanged, and the concluding dance will be performed, in appropriately democratic style, by women members of the Swinish Multitude, dancing in their pattens. ${ }^{53}$ Pittachio, like Pinetti, had concluded his advertisements with the loyal wish 'VIVANT REX ET REGINA'; this advertisement ends, once again in the language of liberty, though somewhat fractured, 'Vivant la People Soveraigne.'

\section{VII}

Why were the publishers of these advertisements allowed to go unpunished throughout 1795? By no means all of the advertisements would have been regarded by the law officers of the Crown as seditious libels, at least not as sufficiently obviously so as to make it likely that their publishers could be successfully prosecuted. Prosecutions for seditious libel or seditious words were usually, in the mid 1790s, directed against insults to the king; and though the advertisements produced before the 1794 trials were evidently directed against George, most of those which appeared in 1795 are primarily aimed at Pitt and his ministers. At least two of the advertisements, however, Lee's reissue of the satire on $\mathrm{Ne}-$ buchadnezzar, and his 'An entire Change of Performances?,' quite clearly fell within the category of seditious texts, texts whose tendency was to bring the king into dislike or disrespect, and yet there is no sign that when they appeared the Law Officers contemplated taking action against Lee, as they had against the York publishers of the Nebuchadnezzar handbill. And in fact throughout the twelve months from the acquittal of Hardy to November 1795, they brought no charges of seditious libel in London against the radical booksellers, who in those months were routinely publishing works much more seditious than those which, in 1793 and early 1794, had been routinely prosecuted. This inaction, indeed, on the part of the Law Officers, must be regarded as one reason for the considerable increase in the numbers of popular radical booksellers in the capital in 1795 .

Attempting to justify his inaction to Parliament in November 1795, the Attorney General Sir John Scott declared that there were now simply too many libels published for it to be possible to prosecute them. ${ }^{54}$ This was an odd explanation, for prosecutions for political writings were intended to be exemplary, to have a deterrent effect; the way to stop an epidemic of libels was to prosecute one or two. There are two more probable explanations of the Law Officers' action, or the lack of it. As we have seen, the mock-advertisements began to proliferate immediately 
after the acquittals in the treason trials of late 1794. It seems plain that radical publishers believed, in the radical euphoria that followed the trials, that the government now despaired of securing convictions against radicals in the London courts; that they had, as one pamphleteer put it, suffered a 'knockdown blow' with the collapse of the prosecutions, ${ }^{55}$ and now believed that any prosecution of the radical movement would be regarded by London juries as oppressive and would be thrown out.

There is probably some truth in this; it may also be true, however, that the government was biding its time, waiting for a favourable occasion to introduce more severe penalties against the publication of libels, in the belief, subsequently justified, that this would be a more effective deterrent than prosecution, which always risked appearing oppressive to all but the most convinced loyalists. The occasion came with the attack on the king's coach which I referred to earlier, following which the government immediately introduced the Treasonable Practices Bill, which had probably been drafted a good deal earlier, and which in addition to proposing, as I remarked before, a series of new substantive treasons, also threatened those convicted a second time for seditious libel with transportation for seven years. Two weeks after the introduction of this bill, Richard Lee was arrested and charged with seditious libel.

It was not for any of his mock-advertisements that Lee was to be prosecuted, but principally for a handbill, provocatively entitled King Killing, which advocated regicide as a public benefit, and which, according to the government, had been circulated at a mass meeting of the LCS a few days before the alleged assassination attempt upon the king, and had directly inspired that attempt. ${ }^{56}$ In fact, as Lee explained, the text of the handbill was directly transcribed from an article by John Pitchford published earlier in the year in a Norwich periodical, The Cabinet, which had not been prosecuted; the only substantive change Lee had made, so he claimed, was to change the title from 'Tyrannicide' to King Killing, to ensure that prospective purchasers would know just what they would be buying. ${ }^{57}$ This was not entirely true: Lee omitted to add that the portion of the article he had reprinted was a speech supposed to be made by an advocate of tyrannicide whose arguments the article then went on to condemn. ${ }^{58}$ Before he could be brought to trial, Lee escaped from custody disguised as a woman and made his way to the safety of Philadelphia. ${ }^{59}$ 
VIII

Most of these advertisements were published in the first months of 1795; they remained on sale at least until the autumn of that year, months after the immediately topical events they refer to had ceased to be news. A part of their remarkable contemporary success is that they mobilise a figure frequently used in propaganda, satire and polemics against Pitt's ministry. The figure was developed most extensively by Francis Plowden, the first historian of the early and middle 1790s in Britain. In 1794 and 1795, Plowden became increasingly radicalised, more and more convinced that the political machinations of the government, and particularly the alarms it had raised about the ultimate ambitions of the movement for parliamentary reform, were the concerted parts of a grand design, a conspiracy to appropriate power from the institutions of popular representation - the House of Commons and the jury - to the throne. With remarkable singlemindedness, Plowden dramatised this belief by a play on words, a figure already familiar in eighteenth-century political satire but perhaps nowhere else so tirelessly elaborated, by which this conspiracy, this plot, was imagined as the plot of a play or a sequence of plays, staged by ministers who are repeatedly represented as the 'managers' of the theatre of politics.

Plowden pursued this figure most exhaustively in his discussion of the 1794 treason trials, Pitt's 'grand exhibition.' He describes the preceding treason trials in Edinburgh as the 'prelude' or the 'first act' of a drama, which Pitt had decided to try out in 'a country theatre' before making the final decision to exhibit the whole piece, the twelve consecutive trials of the London radicals, at the Old Bailey. The convictions in Edinburgh, Plowden tells us, 'encouraged the Managers to prepare immediately' for this 'grand exhibition.' 'Such was the confidence of success, he continues, 'that it was first announced for twelve successive nights, and the whole company, with an unexampled troop of attendants, servants, mutes, prompters, \&c. \&c. were accordingly retained at the most exhaustive salaries.' The great drama was extensively advertised: 'none of the stale and hackneyed arts of inflated merit and anticipated success were omitted.' When the piece was eventually put on, however, 'it was thrice damned by the audience on so many separate performances,' and was promptly taken off. Hardy, Tooke and Thelwall were all acquitted, in a series of creaking productions in which 'the connection of the plot, the shifting of the scenes, and the wonderful deception of the machinery' were only too apparent. ${ }^{60}$ It is to this figure, as it appears in Plowden's writings and in others, similar if less elaborate and less sophisticated, that the various bills refer which announce dramatic representations of the treason trials, of Dundassio's own 'grand 
exhibition'; of the war against France, and of a series of other moments in Pitt's great plot; most explicitly perhaps in a late bill, from the summer of 1795, advertising A New Tragedy, entitled, Another Campaign (fig. 11). This assures the Public, 'that whatever Defects they may perceive in the Contrivance and Management of the Plot, they shall have no Reason to complain of Expence being spared, or of the want of TRAGIC EFFECT in the Catastrophe. ${ }^{61}$

The chief originality of the playbills, however, what made them at once so novel and so popular, does not lie in this figure, nor in the general idea of making political satire out of advertisements, even of showmen's advertisements - that idea is at least as old as Swift. ${ }^{62}$ It is that by focusing not on the theatre itself but on theatre advertising, they had found a new way of representing what was a thoroughly familiar notion, politics as theatre, political plots as the plots of drama, in a way which made that notion especially accessible to a popular audience. The originality is in printing the mock-advertisement in a form which releases it from the context of the satirical pamphlet, and allows it to be stuck up, or imagined as stuck up, in the tavern and the street.

I can begin to explain what I mean by suggesting that one of the most intriguing things about these advertisements is that they confuse the tidy division we often make, in studying radical political culture in the revolutionary period, between polite and popular culture. These mock advertisements were invariably printed by booksellers who aimed at a popular radical market, with little disposable income or formal education. Even among popular booksellers there was a clear social hierarchy, divisions of class and status marked by the length and cost of their publications, the size of their premises and the way those premises were used. These handbills were published by the lowest of the low, the most popular of the popular, the most plebeian of the plebeian. But it is not at all clear how many of them were written by members of that social group. We know that the first Pittachio advertisement was produced by the polite, public-school-educated poet Robert Merry, who had first satirised Pitt as a showman in his play The Magician no Conjurer, produced at Covent Garden early in $1792 .{ }^{63}$ It's probable that the second in the Pittachio series was produced by the Foxite M.P. Joseph Jekyll, a lawyer from a distinguished legal family, with the reputation of being quite a wag. ${ }^{64}$ Jekyll and Merry were both friends and political associates of Sheridan; Jekyll was a member of the same opposition grouping in the House of Commons, and Merry was a member of the polite and moderate reform club the Friends of the People, to which Sheridan also belonged. It seems quite likely that two more of these satires originated in Sheridan's circle. One mock-advertisement, for the pantomime Royal Vagabonds (fig. 12), advertises an after-piece entitled 'The Wonders of 
Gallia!' which recalls the elaborate show The Wonders of Derbyshire, designed by De Loutherbourg, which had been staged under the management of Sheridan at Drury Lane in $1779 .{ }^{65}$ The satire on Dundassio includes the announcement of a play entitled 'The King's Friends; or, The Dupe,' evidently a satire on the apostate Whigs who had gone into coalition with Pitt's government in the summer of 1794 . Its title recalls the comedy The Dupe written by Sheridan's mother Frances, which had been repeatedly hissed during its brief run at the same theatre in $1763 .{ }^{66}$ By early 1795, neither of these references would have meant much outside the circle of Sheridan, within which, however, they would still have meant a good deal. 'George's Head in the Basket,' as we have seen, was attributed to a 'gentleman;' on the basis of internal evidence, the style of Another Campaign seems to indicate a polite author also ${ }^{67}$ Indeed, perhaps only Amusement for Starving Mechanics, with its language of popular religious dissent, and An entire Change of Performances?, with its fractured French, seem to me likely to have been written by more or less 'vulgar' authors.

But the evident popularity of these advertisements, among radicals whom Merry, Jekyll and Sheridan would no doubt themselves have regarded as 'vulgar,' suggests that the theatrical culture to which they referred - or rather that the language of theatrical advertising they employed - was one which could function as something like a common language of satire, engaging the interest and knowledge of the polite, the vulgar and a broad range of cultural identities between politeness and vulgarity. It could do this probably more effectively than the language, or rather the languages of formal political debate, which differed widely according to the class identity of author and supposed audience. The humour of these advertisements, and the attempt they make to represent politics as theatre, as spectacle, as illusion, are not at all dependent upon an appeal to any familiarity with the theatre itself. For though cheap versions of many of the tricks of showmen like Pinetti could be seen by the most vulgar at Bartholomew Fair, ${ }^{68}$ for example, these broadsides are modelled on advertisements for entertainments that few radical artisans or labourers could afford to attend: entrance to Pinetti's show cost two shillings and sixpence, ten times as much as to see 'La Guillotine;' this at a time when the high admission charges for public entertainments were justified as guaranteeing the exclusion of the vulgar. But the mock-advertisements mobilise a language with which any reader of newspapers, anyone indeed walking the streets of London, would have been thoroughly familiar.

We could describe the mock-advertisements as inviting into the theatre of politics those excluded from both theatre and politics, as offering them the chance to discover that the politics of the ancien régime is an art 
of deception, and so of becoming undeceived. In many cases, however, the fine print of the invitation should be read with some suspicion; a common language is no guarantee of a common purpose. At first glance, 'La Guillotine; or, George's Head in the Basket' appears to be the most seditious of all these advertisements, offering the swinish multitude a front seat at the extinction of the hereditary monarchy, at a revolution which is imagined, however, not as their revolution, but that of the small Whig élite whose political objectives fell far short of the universal manhood suffrage demanded by the radical societies. Something similar is true, for example, of the pantomime Harlequin Impeacher, in which the heroes of the grand finale, the 'Storming of the Cabinet,' are Earl Stanhope the radical peer, another selection of aristocratic Whigs, and Horne Tooke and Thomas Holcroft, members of the polite and middle class Society for Constitutional Information. The 'Serio-Comico-Dramatico Medley' advertised in Pittachio's third announcement has a huge cast of wicked loyalists and virtuous patriots, only two of whom, Hardy and Thelwall, could pretend to represent the vulgar.

Most of these advertisements, I am suggesting, invite the vulgar to participate in the performance of politics, to 'make a scene,' to boo the government. By the figure of the theatrical audience, the vulgar are imagined as an active 'popular' or even 'public opinion' which will hiss Pitt from office, but in the expectation that they will then cheer Fox to the stage; will applaud, huzza, be enthralled by, the 'Sublime and Animating Spectacle' of power passing into the hands of another set of hereditary aristocrats and polite career politicians. These men, they are asked to accept, are their leaders; the actions of these men, they are invited to believe, will be (to quote one playbill) 'Pro Bono Publico'; the 'Theatre of the World,' they are told, is the theatre of the British Parliament; the revolution is to be delivered by a handful of Whigs whose admirable record of opposition to the war and to Pitt's attack on civil rights will persuade their audience to overlook the fact that they offer only the most moderate political reform. It may be indeed that one of the reasons for the popularity of these texts is that they spoke to a residual deference in the popular radical movement, the sense, so hard to shake off, that men of title and distinction really were their natural leaders, however suspicious members of that movement had learned to become about the pretensions to rule of the ruling-class; this residual and reluctant deference is one of the things that distinguish, I think, the movement of the 1790 s from the Chartists of forty and fifty years later. In this context especially, the mock playbills make sense of the question-mark in the title of An entire Change of Performances?, the only advertisement which represents the swinish multitude as actors as well as audience in the imagined revolution. We can read that query as pointing to a continuing 
dilemma in the popular radical movement about how far it could use an aristocratic parliamentary Opposition which it admired but did not trust, which sought to use it but did not trust it. ${ }^{69}$

\section{JOHN BARRELL \\ University of York}

\section{Endnotes}

1 Vicesimus Knox, A Narrative of Some Transactions relative to a Sermon, preached in the Parish Church of Brighton, 2nd ed. (London: C. Dilly, 1793).

2 W. Curtis, A Narrative of an Assault, and other Disgraceful Outrages, lately committed on a Peaceable Individual, by a Set of Military Heroes, at the Theatre, in Lynn Regis ('London printed, And may be had of the Booksellers in Town and Country,' 1794). The pamphlet is dated March 18.

3 T.B. Howell and Thomas Jones Howell, A Complete Collection of State Trials (London: Longman et al., 1816-22), 24:82-3; for an earlier riot in the Edinburgh Theatre, in October 1792, see James Mackay, A Biography of Robert Burns (Edinburgh: Mainstream, 1992) 520.

4 The most famous such incident occurred on the night at the theatre in Dumfries in October 1792, when Robert Burns either refused or (if we prefer his own version) did not refuse to stand and remove his hat when 'God save the king' was performed: see Mackay, Biography 518-20, and The Letters of Robert Burns, ed. J. De Lancey and G. Ross Roy, 2nd ed. (Oxford: Clarendon Press, 1985) 2:165-6.

5 [Robert Thompson], A New Song to an Old Tune ('God save - "THE RIGHTS OF MAN!' ' (no publication details); 'God save great Jolter-Head' is referred to in the trial of John Thelwall, State Trials for High Treason. Embellished with Portraits (London: B. Crosby, [late 1794 or early 1795]) 3:21. The Dog's Day: an Ode. By J. Hogg, A.M. of Grunter's College (no publication details), looks forward to the hanging of George, Pitt and Dundas; A Cure for National Grievances [.] Citizen Guillotine. A New Shaving Machine (London: Richard Lee [1795]) represents hanging as too cruel a punishment for Pitt, and recommends instead the French method of execution; see also the song The Tyrants of Britain (no publication details [1795]). 'On the French Revolution,' in The Moral and Political Magazine of the London Corresponding Society 1:144; God save the Prince (no publication details [1795]), attacks the Prince of Wales's expenditure, which it estimates at 'Two hundred pounds a day.' The Duke of York's New March (London: Richard Lee [1795]). There are various loyalist songs also, written to be sung to the tune of 'God save great George our King.'

6 The Life of John Thelwall. By his Widow (London: John Macrone, 1837) 1:285-6. This and the following paragraphs on performances of Venice Preserv'd in 1794 and 1795 are discussed at greater length in my essay 'Popular Political Culture in the Mid 1790s,' Anglistentag 1995 Greifswald: Proceedings , ed. Jürgen Klein and Dirk Banderbeke (Tübingen: Max Niemeyer Verlag, 1996) 15-27.

7 The theft of Venice Preserv' $d$ had probably been started by Eaton, who in 1793 had used brief extracts from the play as epigraphs on the title-pages of two radical 
pamphlets: see Charles Pigott, Persecution. The Case of Charles Pigott: containing the Defence he had prepared and which would have been delivered by him on his Trial, if the Grand Jury had not thrown out the Bill preferred against him (London: D.I. Eaton, 1793); Extermination, or an Appeal to the People of England, on the Present War, with France (London: D.I. Eaton, [1793]). For Thelwall's theft, see the evidence of the spy John Taylor before the Privy Council, PRO TS11/963/3609, and State Trials for High Treason ... embellished with Portraits 3:35-5.

8 The Speeches of Pierre and Jeffeir, extracted from Venice Preserved (no publication details).

9 True Briton October 301795.

10 Life of John Thelwall 1:286.

11 A Narrative of the Insults offered to the King, on his Way to and from the House of Lords ... By an Eye-Witness (London: J. Owen, 1795) 11-12. See also the True Briton October 30, November 2 1795; Times October 31.

12 State Trials 24:84.

13 James Parkinson, the anonymous author of $A$ Vindication of the London Corresponding Society (London: J. Smith and J. Burks, 1794), justly complained that this satire was a violation of law and justice which, published in the confidence that it would not be prosecuted, 'describes those men who are awaiting the verdict of their country, as having fully perpetrated those acts of high treason of which they are supposed to be accused, but of which a fundamental principle of our constitution declares them to be held innocent until their guilt is proved' (4).

14 Among the few mock-advertisements I will not have space to discuss in this essay or mention in the notes, the most interesting are the six parts of Exhibition Extraordinary!!, a mock art-exhibition, originally published in the Telegraph and reprinted as broadsides (London: G. Riebau, [1795]).

15 For the Benefit of the Tythe and Tax Club (no publication details [1794]). This handbill was complained of by Samuel Buck in a letter from Leeds to John Scott, February 19 1794. The Treasury Solicitor, Joseph White, responded with an indictment against a man named Brownrigge, who had published by distributing it in York. But Brownrigge absconded, and on the advice of White the same indictment was used against the prominent Leeds radical Charles Handley, who also 'published' the handbill; see PRO TS11/591/1936; for Handley's trial, see Oracle April 5 1794. A few months later George Thompson was acquitted in York on a charge of publishing the same handbill, in a verdict which acknowledged that he had published it but denied that it was seditious: see Clive Emsley, 'An Aspect of Pitt's "Terror": prosecutions for sedition during the 1790s,' Social History 6 (1981): 171.

16 It was first reported to the Government in London by the spy John Taylor, who recorded that at a special meeting of the LCS on February 281794 the handbill had been read aloud by George Williams, a leather-seller from Smithfield. Taylor added that it gained 'great applause' and that he 'understood it was the production of the constitutional Committee' (a committee of the LCS charged with examining its constitution and organisation. See Selections from the Papers of the London Corresponding Society 1792-1799, ed. Mary Thale (Cambridge:

Cambridge UP 1983) 118 and n. Thale confuses this handbill with Lee's re-issue of it, with a new title, in 1795: see below. The possibility of a Yorkshire origin for the handbill may be supported by verbal similarities between it and A Serious Lecture. 
A Public Meeting of the Friends of Peace and Reform [Sheffield: John Gales for the Sheffield Society for Constitutional Information] 1794.

17 See State Trials 24:794-5 and Thale 83. Lynam reported to the government that Cruden was rumoured to be in the pay of the French Convention, but this was probably invention on his part or the part of his informants - we would probably know more of Cruden had it been true.

18 The Second Report from the Committee of Secrecy of the House of Commons (London: J. Debrett 1794) 26.

19 See for example the interrogations of John Edwards, Thomas Hardy and George Williams, PRO TS11/963/3509; Edward Gosling, John Hillier, PC1/22/A36/A; John Francklow and Edward Hodson, PC1/22/A36/B; John Pearce, $\mathrm{PC} 1 / 22 / \mathrm{A} 36 / \mathrm{C}$. Edwards told the Privy Council that he had received this broadside playbill from John Baxter, a member of the LCS who was indicted for high treason at the same time as Thomas Hardy; see Edwards's examination of May 26 1794, PC1/22/A36/B.

20 For the existence of an earlier, handbill-sized version, dated 'January 30' (the anniversary of the execution of Charles I), and first published in October or November, see the examination by the Privy Council of John Edwards, a member of the LCS, May 27 1794, PRO TS11/963/3509, his evidence in Hardy's trial, State Trials 24:681, and the examination of the government spy Edward Gosling, PC1/22/A36/A. Edwards had displayed the advertisement in his shop.

21 See Thomas Spence, The Coin-Collector's Companion (London: Spence, 1795).

22 William Carter, an illiterate bill-sticker, was arrested in December 1792 for posting copies of the LCS's Address of the London Corresponding Society, to the other Societies of Great-Britain. He was tried and found guilty the following month; see PRO TS11/965/3510A, and Thale, Selections 34n., 36n., 42-6.

23 Wordsworth, The Prelude (1805) 7:213-4.

24 Wordsworth, The Prelude 1799, 1805, 1850, ed. Jonathan Wordsworth, M.H. Abrams and Stephen Gill (New York and London: W.W. Norton, 1979) 236, nn. 4,1 .

25 State Trials 25:381-6.

26 Space prevents a discussion here of satires of Pitt's forgetfulness. It was a feature of all the 'Pittachio' broadsides discussed; the last of these, Sale Extraordinary of the Effects of Signor Gulielmo Pittachio (no publication details [1795]), offers his memory - 'of very fine Tone, but kept below Concert-pitch at the option of the Owner' - among the items for sale. The broadside is signed 'A.L.,' and in the advertisement leaf of a publication of 1795 by John Smith, Corrupt Parliaments: An Extract from Alexander Scott's Legacy to his Country, it is described as 'by a Lady.' In one satirical poem, possibly by Robert Merry, Pitt's forgetfulness was represented as the effect of his hopeless love for 'Polly Power;' see Pitti-Clout \& Dun-Cuddy, a Political Eclogue; wherein is expressed in courtly lays, the Inviolable Attachment and Constant Loves of the Treasury Shepherds, and their Firm Resolutions to Sacrifice Everything to their Respective Sweethearts, Polly Power and Sally Plunder. By Mr. $M-R-Y$ (London: Citizen Lee: [1795]) 6 [but note that in the advertisement leaf of Mr. St. George, a True Story (London: Citizen Lee, 1795) is the note: 'Pitti-Clout \& Dun-Cuddy, a Political Eclogue, was erroneously said to be written by MR. M-R-Y']. Walter Savage Landor attributed Pitt's forgetfulness to hard drinking: see [W.S. Landor], Moral Epistle, respectfully dedicated to Earl Stanhope (London: 
T. Cadell junr. and W. Davies, 1795) 13; in an anonymous song, 'The Patriot, or Billy the Apostate,' it seems to be connected with a habit of masturbation: see The Patriot, or Billy the Apostate (no place: 'Margaret Nicholson,' 1795), where a reference to Pitt's devotion to 'His manual exercise' immediately precedes an account of how his memory failed him at the Old Bailey. Some of the more interesting and amusing satires of Pitt's amnesia include the Morning Chronicle November 27 1794; the Morning Post January 13 and February 12 1795; 'A Crambo Epistle to Mr. Pitt, on his memory failing him in a late trial,' in Politics for the People 2: 353-5; John Gale Jones, Sketch of a Speech delivered at the Westminster Forum, on the 9th, 16th, 23d, and 30th December 1794 (London: the author, 1795) 35; A Picture of the Times, in a Letter Addressed to the People of England. By a Lover of Peace (London: J. Ridgway et al., 1795) 15; Telegraph August 20 1795, reprinted as Admirable Satire on the Death, Dissection, Funeral Procession, E Epitaph, of Mr. PITT. [Copied from the TELEGRAPH of the 20th, 21st, and 24th of August, 1795.] (London: C. Smith, Telegraph-Office, [1795]).

27 The first Pittachio pasquinade was enormously popular; it was reprinted in the Courier 'after great demand' (December 29 1794), republished by Spence in Pig's Meat (3:57) and by Eaton in Politics for the People (2:388-9), and appeared in four different editions as a broadside or handbill: two editions of the broadside, both entitled Wonderful Exhibition!!!, appear with a woodcut of Pitt with a bell and book; in one of these he is flanked on either side by the royal arms; a third version (with the same title but no exclamation marks) appears in the Place collection at the British Museum. In the handbill 'Wonderful Exhibition' (no publication details [1794/5]), the pasquinade is paired with the song 'The Political Bellman's Address.'

28 Advertisements for the shows of numerous illusionists and other 'magic' showmen are preserved in the John Johnson collection, Bodleian Library, Oxford and in volumes one and two of the Daniel Lysons collection in the British Library (Collectanea: or, a Collection of Advertisements and Paragraphs from the Newspapers, relating to Various Subjects).

29 'Pitt and Pinetti. A Parallel,' Political Miscellanies 89-91, separately paginated in The Rolliad, in Two Parts: Probationary Odes for the Laureateship; and Political Miscellanies, 1784-91 (London: J. Ridgway, 1795).

30 'The Three Conjurers;' the Prussian is Katerfelto, the Englishman Breslaw, the Italian Pinetti; see Lysons's Collectanea, 2:1, 212. Pinetti was still a thoroughly familiar name in 1795. 'Signor Pinetti' gets a footnote - which treats him as a household name - in Peter Pindar's The Royal Tour, and Weymouth Amusements (London: J. Walker et al., 1795) 28n.

31 By Permission of the Worshipful the Mayor. Hereford, April 6, 1795 (Hereford: D. Walker, 1795).

32 See 'Pitt and Pinetti,' which explains that 'Mr. Pitt's method of leaving us in the dark is by BLOCKING UP OUR WINDOWS!'

33 Lysons, Collectanea, 1:209; see also Breslaw's 'Sympathetick BELL,' 1:189.

34 Again, see 'Pitt and Pinetti' (Political Miscellanies, 91): 'PINETTI has a bird which sings exactly any tune put before it. - Mr. PITT has upwards of TWO HUNDRED birds of this description.' There are various other parallels in the parallel between Pitt and Pinetti in The Rolliad which resurface in the Pittachio pasquinades. 
35 No. II. More Wonderful Wonders (no publication details) was first published in the Courier on December 15 1794. It reappeared in Politics for the People 2:406-7.

36 See Lysons's Collectanea 2:1 and 212.

37 The aspersions on Pitt's potency in the 1790s are too many to list; they may begin in the previous decade with the series of epigrams at 21-3 of Political Miscellanies in The Rolliad.

38 Wonderfull Exhibition! positively the last Season of his Performing. Signor Gulielmo Pittachio (London: Richard Lee, 1795).

39 Alluding to the arrests of May and June 1794, prior to the treason trials, and the judge's assurance to Thomas Holcroft, on his discharge, that there was nothing to complain of in his treatment by the Privy Council or the Crown Lawyers (State Trials ... Embellished with Portraits, 3:6-7). Though it appeared after the event, the advertisement was probably intended to satirise the debate on the renewal of the Habeas Corpus Suspension Act on January 23; on February 9 the Courier published a review of the debate supposed to have taken place at 'Pittachio's Theatre Royal.'

40 Sale Extraordinary (see above, n. 25); the Courier, February 9 1795; the Telegraph September 101795.

41 Morning Post February 121795.

42 Pittpache's Requisition ([London]: J. Bullock, [1795]). This is a mock-proclamation, but it employs the style of the typographical style of the mock-advertisements.

43 Three Pittander broadsides - Mustapha's Adoration Part I ([London]: George Riebau [1795]) and Part II, and Mustapha's Vision (no publication details but presumably Riebau 1795) - have survived; probably all originally appeared in the Courier, but in the defective collection of the Courier in the Burney collection at the British Library I have found only the second, on January 22 1795. The Telegraph March 231795 published an account of a manufactory owned and run by a Mr. Pittfall which produced 'Demoes and Repubs;' for other elaborate satires of Pitt, see the Telegraph August 20, 21, 24, September 15, 16, 19.

44 Pro Bono Publico. Speedily will be Performed, on the Vast Theatre of the World, ... Harlequin Impeacher (no publication details [1795]).

45 The London Stage 1660-1800 ... Part 5, ed.Charles Beecher Hogan (Carbondale: Southern Illinois University Press, 1968) 1606-7.

46 Grand Exhibition at Wimbledon!!!. On Wednesday, the 25th of February, the Famous Sieur Henrico Dundassio (no publication details [1795]).

47 The point is especially well made in Song on the General Fast ... February, 25, 1795 (London: Thomas Spence 1795) and by 'Ebenezer Verax' (probably = Daniel Isaac Eaton), A Wonderful Sermon; or, Truth Disguised. Intended to be preached on the Fast-Day ... Together with An Hymn, and a Proclamation (London: Eaton, [1796]), which describes the proclamation of the fast as a 'Proclamation for a General Starvation, by the King of Hog Island:' 'We ... hereby command, that a Public Starvation, and Degradation, be observed by all the Poor, who cannot procure food throughout our dominions, on Wednesday, the Twenty-fifth of February next' (3-5). See Michael T. Davis, 'Daniel Isaac Eaton,' in British Reform Writers, ed. Gary Kelly and Ed Applegate (Detroit: Gale Research: Dictionary of Literary Biography vol. 158, 1996) 100.

48 Amusement for starving Mechanics (London: Richard Lee [1795]). 
49 For more on this advertisement, and on George III as Nebuchadnezzar, see my essay 'Imagining the King's Death: the Arrest of Richard Brothers,' History Workshop Journal 37 (1994): 1-32.

50 Grand Order of Procession at the first formal Entry of Louis XVII into his City of Paris (London: Richard Lee, [1795]).

51 'Changeable' silk is what I was brought up to call 'shot silk;' it is well described by Lord Chesterfield: "There is such a connection between licentiousness and liberty, that it is not easy to correct the one, without dangerously wounding the other: it is extremely hard to distinguish the true limit between them: like a changeable silk, we can easily see there are two different colours, but we cannot easily discover where the one ends, or where the other begins;' quoted by Thomas Erskine in his defence of Paine, State Trials 22:442-3.

52 An entire Change of Performances? (London: Richard Lee, [1795]).

53 The dance of 'Female Pigs in Pattens' seems here to allude to Samuel Foote's famous puppet-play version of Pamela, The Handsome Housemaid; or, Piety in Pattens, produced at the Haymarket, 1772-3. My thanks to Jane Moody for providing this reference.

54 Parliamentary History 32:488.

55 The Age of Prophecy! or, Further Testimony to the Mission of Richard Brothers. By a Convert (London: Parsons et al., 1795) 28.

56 See PRO TS11/837/2832. Rex v. Lee. The file contains numerous works published by Lee, and three draft indictments, one of them concerning King Killing. For the claim that King Killing inspired the attack on the king, see the speeches of Windham, Canning, and (especially) the Earl of Mornington, in Parliamentary History 32:298, 301, 332-3.

57 See The History of Two Acts (London: G.G. and J. Robinson, 1796) 368-9.

58 The Cabinet. By a Society of Gentlemen (Norwich and London: John March and J.S. Jordan, 1794-5) 1:69-71. The fullest account of The Cabinet, its contents and contributors, is Youth and Revolution in the 1790s: Letters of William Pattison, Thomas Amyot and Henry Crabb Robinson, ed. Penelope J. Corfield and Chris Evans (Stroud: Alan Sutton, 1996) passim and especially 187-95.

59 See Times December 19 1795, and True Briton January 231796.

60 Francis Plowden, A Short History of the British Empire during the Year 1794 (London: G.G. and J. Robinson, 1795) 240, 247-8.

61 In Preparation, and speedily will be Performed, ... A New Tragedy, entitled, Another Campaign (no publication details [1795]). This text, advertising also a comic after-piece, 'John Bull turned into a Milch Ass,' is a revision and expansion of what I take to be its first version, in the Telegraph of July 161795.

62 For a good account of earlier political satires based on advertisements, see Marcus Wood, Radical Satire and Print Culture 1790-1822 (Oxford: Clarendon Press, 1994) $18-56$.

63 Attributed to Robert Merry in the obituary notice of him in the Monthly Magazine 7:257 (April 1799), with the comment that 'no minister in any age had been so ridiculed before.' For a discussion of this pasquinade, see Wood, Radical Satire 82-5, which replaces the account in his 'Thomas Spence and Modes of 
Subversion,' Enlightenment and Dissent 10 (1991): 65-67, where it is mysteriously attributed to Thomas Spence.

64 There is a manuscript copy of this squib in the John Johnson Collection at the Bodleian Library, Oxford, which attributes it to Jekyll. There is no reason to believe it is in Jekyll's hand, but it seems improbable that anyone would think of attributing the squib to him without some evidence of his authorship. Wood (Radical Satire 85) attributes it to Eaton; he does not give his reasons, but perhaps he came across it in Eaton's Politics for the People and was unaware that it had originally appeared in the Courier. For Jekyll's waggery, see The Rolliad 243-8 ('Jekyll, the way of law,' etc.).

65 By general Desire. ... An entire new Pantomime, called The Royal Vagabonds (London: Richard Lee, 1795); The London Stage 1660-1800 ... Part 5, ed. Charles Beecher Hogan, 227. The Wonders of Derbyshire is attributed to Sheridan himself by G.W. Williams ('A New Source of Evidence for Sheridan's Authorship of The Camp and The Wonders of Derbyshire,' Studies in Philology 47 (1950): 624-7). Cecil Price regards the attribution as 'possible' but unproven; see his edition of The Dramatic Works of Richard Brinsley Sheridan (Oxford: Clarendon Press, 1973) 2:817.

66 The London Stage 1660-1800 ... Part 4, ed. George Winchester Stone, Jr. (Carbondale: Southern Illinois University Press, 1968) 1024-6.

67 See above, note 64 . The impression that this is the production of a polite author is rather clearer in the broadside than in the newspaper version, though in the former the cast of the tragedy now includes a number of government spies, most of whom were infiltrators of the LCS. 'Signor Pittini' in the original version becomes 'Mr. Bottomless Pitt' in the broadside, perhaps an indication that the representation of Pitt as an Italian showman was now felt to have become old hat.

68 See Richard D. Altick, The Shows of London: a panoramic history of exhibitions, 1600-1862 (Cambridge MA: Harvard University Press, 1988) 62.

69 My thanks to Mike Cordner, Kate Davies, Harriet Guest, Tony Inglis and Jane Moody for the help they gave me while I was researching and writing this essay. Thanks also to those who listened to and questioned me about this paper at the Universities of Victoria, B.C. (where in October 1996 its first version was delivered), Johns Hopkins University, and the universities of Pennsylvania, Sussex, Warwick, and York. 


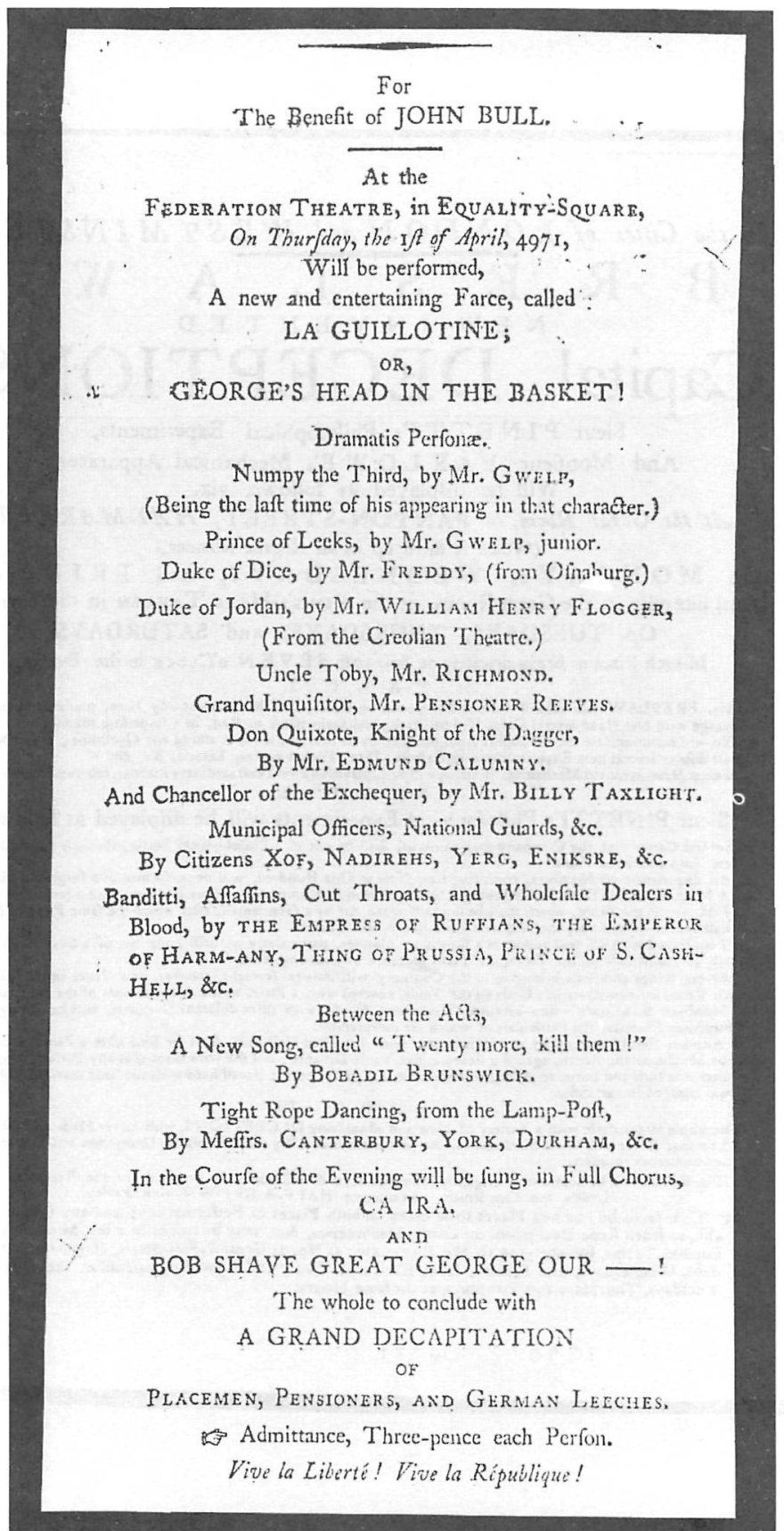

Figure 1. 'For the Benefit of JOHN BLLL' 
In the Citive of LONDON and WESTMINSTER B R E S L A W's N E W.I N V E N T E D Capital DECEPTIONS

Sieur PINET TI's Philofophical Experiments,

And Monfieur B A R L W E's Mechanical Apparatus, Will be difplayed as follows, viz.

At the Great Room, in PANTON-STREET, HAY-MARKET, (Which is futed up in an elegant Manner, )

On. MONDAYS, WEDNESDA YS, and FRIDAYS; And likewile in the Great Room, at the King ${ }^{\circ}$-Head TAvern in the Pouliry, $\therefore \quad$ On TUESDAYS, THURSDAYS, and SATURDAYS.

Jri each Place to begin preciftly at half pan SEVEN o'Clock in the. Evening. $P$ A R T 1 .

1. Mr. BRESLAW will exhibit various Deceptions on Carda, in a Manner entirely New, parricularly he will change with one Hand feveral Cards Red to Black, and again Hlack to Red, in a furprifing Manner.

12. He will cotnmunicate the Thoughts from onc Perfon to another, without alking any Queftions; afier which he will difplay feveral new Experiments with Cafkets, Dice, Pocket-pieces, Letuera, \&ce. \&e.

S. Sevasal New-inzenued Mechanieal Watches will be difplayed in anool exusardinary mannes, toonumerous to infert. P A R T II.

Sieur PINETTI's Philofophical Experiments will be difplayed as follow :

2. Several Cards that the Company may think of, Alail ty out of a Philofopthical Bottle, through a little Shovel, one $Y_{\text {ard }}$ above the Table.

2. An Experiment on Numbers, confiting from Ten to One Hundred, will be performed in a furprifing Manner. 3. A Mechanical P1STOL hali he charged by any Perfon in Company, and any Lady may put a remarkabic Piece of Money in the Piftol, which thall be fired off it? lhe Air by a Gentleusa, after which the fame Piece of Money thall appear immediately inciofed in a Gold lios on the Table.

4. T wo hetele FKIARS will appear in a fuiprifing Manner, particularly one will jump out of a Silver Cup by itfelf, in the Middle of the Table, fix Yarda pigance without any Affitance.

5. Several Rings and Seals beionging to the Company will anfwer foveral Queftions, and dance in the Middle of 5. the Room by ilsemfelves in a Gials on the Table, covered with a Plate, to the Aftonithment of tbe Spetators.

6. Monfieur Han Lown's new-invented Miechanical Chich, with thiee different Divifions, will be difplayed in a

forprifing Manner, the Particulars of which are inexpreffible.
7. Another Piftol, chiarged by any Genticinar, wilh a marked Nail in it, Thall he fired after 2 Pack of Cards in the Middle of the Room, againit a Loard at five Yards Ditiance; and the fame Card that any Perion thought on, after ir is torin and burnt to Afhes, will appesr in an Inflant on the Hoard fixed with the fame marked Nail whick was charged in the Pattol.

$$
\text { P A } R \text { R I II!. }
$$

The whole to conclude with a Variety of New and aftonilhine DECEPTIONS, with Silver Medals, Gold Boxes, Lemons, Silver and Glafs Machineries, \&c. and more than Fifty ober furgriting Deceptions and Experiments,

The fooms will be kept warm, elegantly illuminated, and cammodioufly prepared for the Reception of the Ladies and Gentiemen. Admitiance HAI.F.A.CROWN wes Perion.

67 Tickets to be had and Places to be taken, at both Places of Performances; and any Perfon inclinable to learn fume Deceptions on Cards, Machineries, \&c. may betaught in a few Minutes, on reafonable Terms, by applying to Mr. BxEatAw, at No. 1, Great Suffolk-Strett, Haymarkat, on Mondays, Wednefdays, and Fridays, from Eleven till Two; and at the Kong's-1Kad in the Poultry, on Tucldays, Thurldays and Saturdays, at the fame Hours.

$$
1790^{\circ} ? \text { Ox JJ }
$$

Figure 2. 'In the Cities of London and Westminster' 


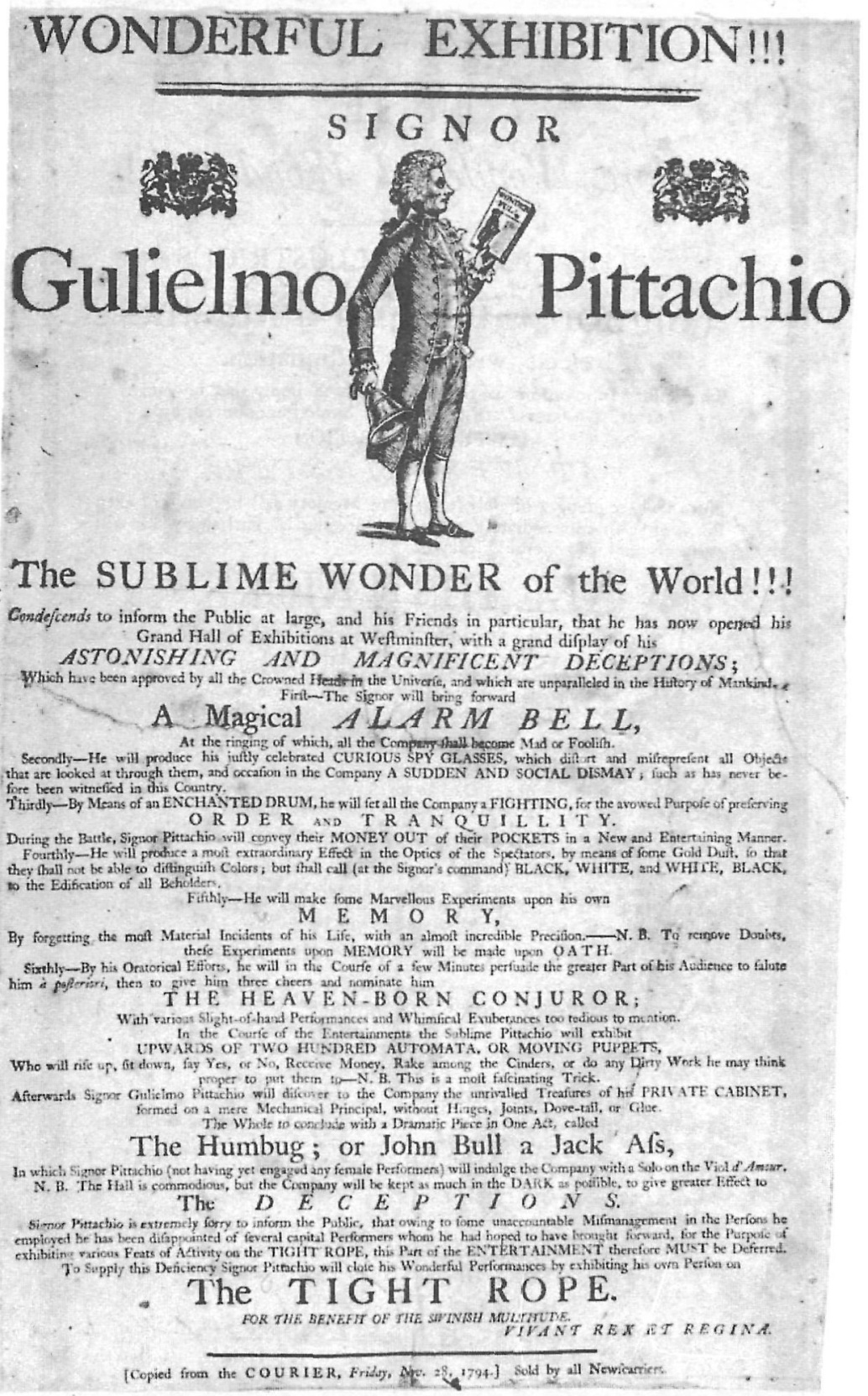

Figure 3. 'Wonderful Exhibition!!! Signior Gulielmo Pittachio' 


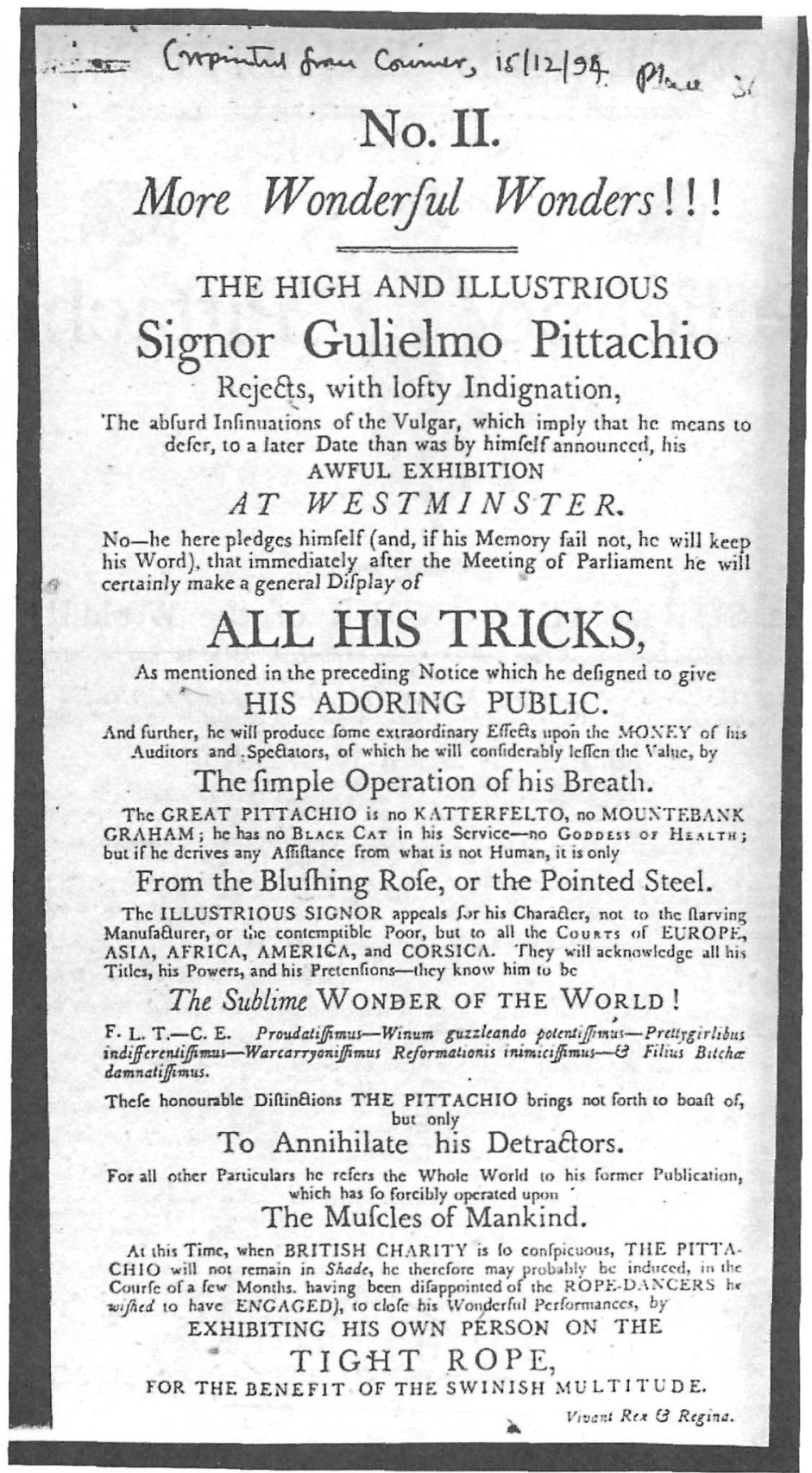

Figure 4. 'No. II. More Wonderful Wonders!!!' 


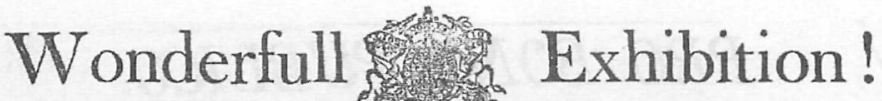

\section{Pofitively the laft Seafon of his Performing. Signor Gulielmo Pittacchio, The SUBLIME WONDER of the World!!!}

Makes known to the Nobility, Gentry, and Swinish Multitude, that, till the expiration of his Licence, he, with the assiftance of his cetebrated and notorious Company, will continue to display a variety of Singular and Whimsical Delusions, with other Divertissements, at his Grand Theatre in Weftminiter, to the altonithment of the World.

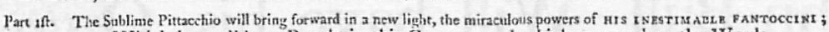

Which have all hetu Bought in this Country, and which can produce the Words,

\section{WAR, TREASON, MURDER,}

and other popular expreffions, as naturally AS IF THEY WERE LIVE CHRISTIANS.

The Grzat Gunse Lato will then propofe to his Anditors, the following paradoxical Enigmas, which he will afterwards explain in the mot incomprehensible manner. Enigma 1, By ruaning backward, wo get forward. Enig., 2, To preferve Health, deflroy the Conftimition. Enig. 3, Absolute Slavery is perfeet Freedom. Enig. 4, Reformation is Aborninatioa. Enig. 5, To be defeated is to conquer.
Jinig. 6, Forgetfulneffs is the beft Memory. Enig. 7, The lefs we have, the more we can throw away. Enig. 8, The Man who speaks the truth is a damned $L$ siar. Enig. A. A Pare is greater than the Whole. And many others, equally lindicrous and amufing. The iruth is a damned Liar. Enig. 9, A Pare is greater than the Whole. And many others, equally Indicrous and amufing.
The famous DoN DUNDEn Ass, commonly salled, the Capital Camelion, will next perform his inimitable Hormpipe; In which he will crofs ores, foot is, and figure in, with an encianting grace, and always precifoly inT Time. The SiGNon and the Doy will then drink

Success to the prefent just and necessary War, in a Gallon of Right Hollands: And will Sing the much admired Duet of

Part 2nd.

$$
\text { "Wible we enjoy sur joval glass, }
$$

A Lecture on the Brain and Heart of a Modern Englifhman; which will be analized,

Phyfically, Hierogliphically, Canonically, Theatrically, Whimfically, Mufically, Algcbraically, Nautically, Sympathetieally,

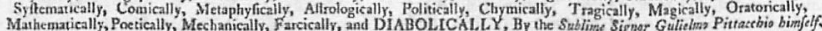

A Humorous Dialogue between JAck Ketch, and a Grown LAwYer, on the fubject of H I GH TREASO N, - With the favourite Air of

Part 3 rd, The Pi 7 racemo will addrefs the Auditurs with the mort laughtable aflirance, and prove to them by Rhetorical Figures, That they have neither Eyes EARS, nor UNDERSTANDINGS.

He will also so alerm them by his fkill in the eccalt Arts, Thar be fhall take them up, knock them down, handcuff them, rummage their pockets, and read their letters, with the mat saptivating dosyrtran and to their perfect Satistaction

Match over

\section{A BARREL OF GUNPOWDER,}

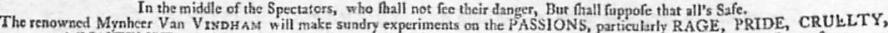
and CONTEMPT - Afier which he will gratifyhe audience with the following exsellent Ballad, of his own Compofing:

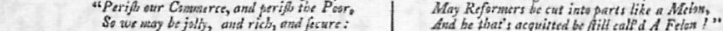

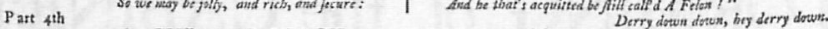
A CURIOUS BLOCK OF SOLID PORTLAND DTONE

Will be exhibited, in the fhape of a human head, which will more its Eyes, Snecze, Yawn, Bluth, and discover feveral fymptons The Subline PITTACCHIO OF REALL EXISTENCE, though in fret it has no power of ation.

The Sublinge PITTACCHIO will then display HIS MASTER TRICK, or, " He plats valtre" of the Art, to the afionifhment of

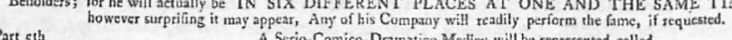

Part 5 th

The Burfting of the Budget, or John Bull's great Bargain. Sir David Demon, ty Signor Pittacelio. Lord Wordeater, Mynheer Van Yindharn. Count Snug. Mr. Mansmead. Numbscull,

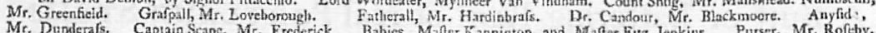
Mr. Dunderals. Capiain Scape, Mr. Frederick. Babies, Manter Kanninton, and Muafter Fitz-Jenkins. Purser, Mr. Rofitby. Siave, Mr. Briton. Good Gesili. Mr. Hareffin, and Mr. Gibfon. Bad Genii. Mr. Reevdy, and Mr. Whitehend. Ghof of

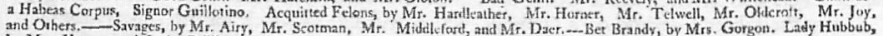

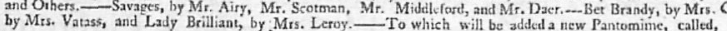

Nay-go and Pray-go, or, Harlequin in Holland.

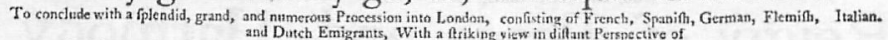

The Palace of Peace, and the Garden of Plenty. N. B. As thare is a great demand for the fitt places, the Nobility and Gentry are carnestly requacfed to arply in time.
No Moncy to be returned.

(Copied from the Telegraph, Thurfday Jantary 29, 1795.) and Sold at the TREE OF LIBERTY, No. 2, St. Ann's Court, Dean Streer, Soho. where may be had a Flaming Panegyric on the Faft Day, Id. Harlequin Statdholdes $t$. Duke of York's New March, sd. and a great variety ot Cheap Pauriotic Publications.

Figure 5. 'Wonderfull Exhibition! Positively the last,' \&c. 


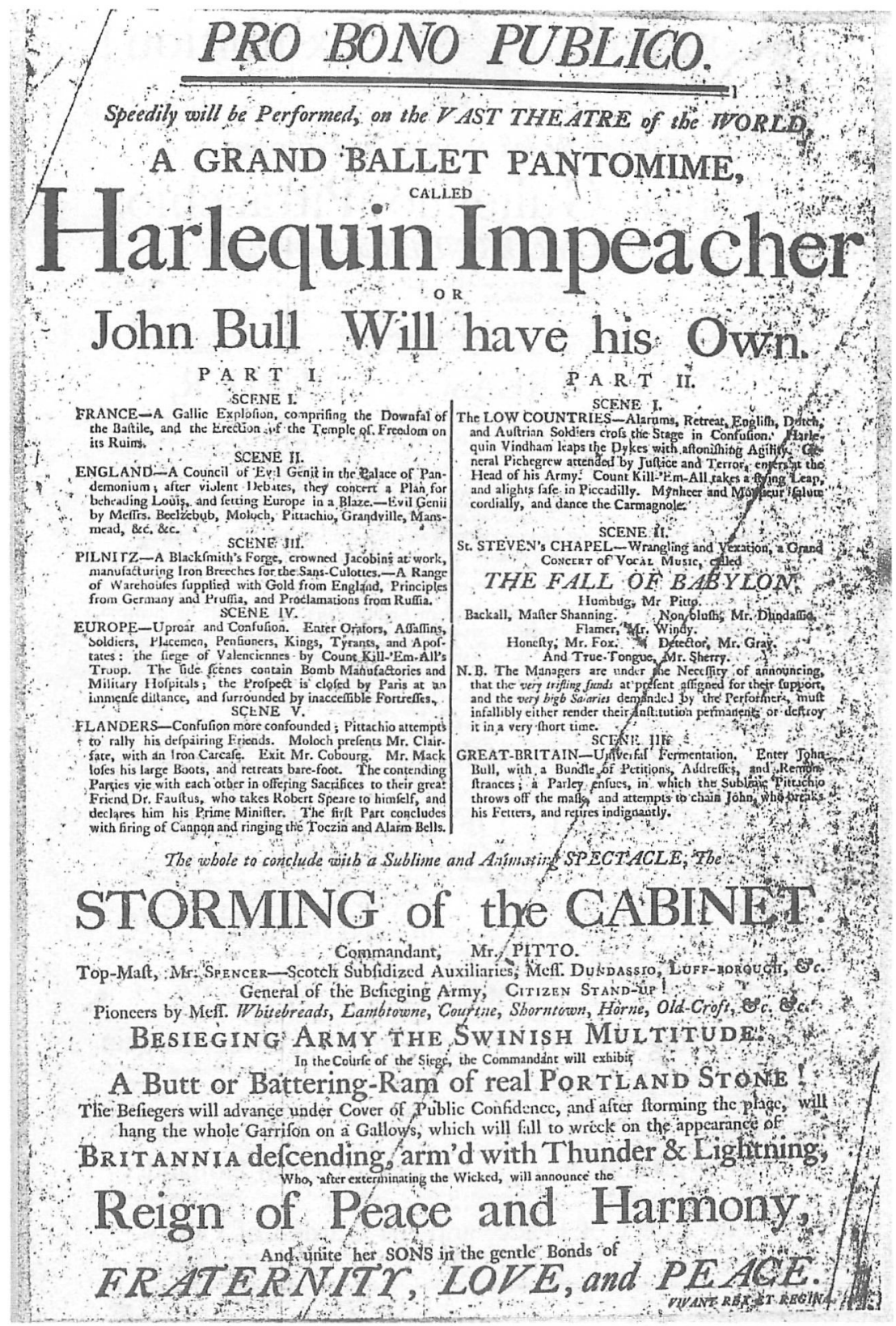

Figure 6. 'Pro Bono Publico' 


\section{Grand Exhibition at Wimbledon!!!"}

On WEDNESDAY, the $25^{\text {th }}$ of FEBRUARY, the Famous

S I E U R

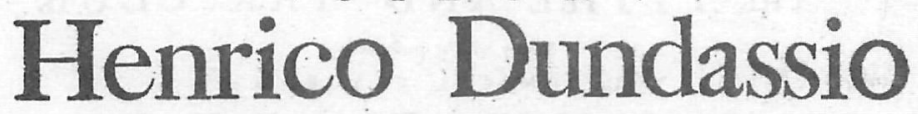

Will entertain a Select Party with Amufements and Devotions fuited to the Day,

\section{A Grand Eating Match,}

By Meffrs. HAWKESBURY and SPENCER.

Which woill prove (beyond all Doubr) the Probability of a FAMINE!

$S E C O N D L Y$,

A BOTTLE ORATION, By the Sublime Pit'tachio, In which he will blend, with the moft familiar Eafe, Wine and Politics, Private Intereft, and Public Welfare, Boc. Boc.

To conclude with a Denunciation of the Jacobins, and a Plan for Marching to Paris !

Thirdly, -An Eflay on the Beneficial Effects refulting from

PLACES AND 'PENSIONS!! by Mafter JENKINSON.

B L E S I N G S OF A P O T T G Y, By the WARLIKR SE CRETARY.

Who will favour the Compainy wieb a Song, entitled

"WAR BEFORE COMMERCE,"

\section{All Under the Table: Or, WINE FLIES UPWARDS! \\ In wbicb, "A FORMOF PRATER" will be red to sbe PROSTRATE COMPANr,} By Cardinal Horsly,

Who has been engaged at a confiderable Expence, and undertakes to prove the Infallibility of the Romilh Religion. The Whole to conclude with a Solemn and Mosal Dratocus, (after the Manner of Peacb'em and Lackit) entitled, WATT's GHOST!

Or, DEAD MEN TELL NO TALES.

The Company are reguefed to pay particular. Antention to tbis Piece, as it developes tbe real Managensent of The SPY STSTEM.

N. B.-If Time and Circumitances will permit, Mr. HAWKESBURY will recite a HUMorous SToRy, of his

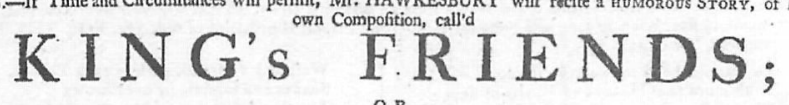

T H E $\stackrel{\mathrm{D}}{\mathrm{R}} \mathrm{U}$ P E.

Which in due Time will be publifbed to the Afonifbnent of the Public.

* $\#$ Sieur HENRICO DUNDASSIO returns his gratefut Thanks to his Friends and the Public for their hitherto znmerited Confidence and Encouragement-and begs Leave to inform them, that, as he entertains fome Apprehenfions of being deprived of

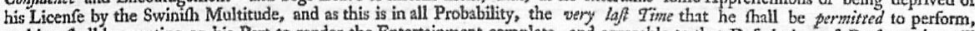
nothing fhall be wanting on his Part to render the Entertainment complete, and agreeable to that Defcription of Perfons who will alone be permitted to partake of it.

Vivant Rex et Regiza. I

Figure 7. 'Grand Exhibition at Wimbledon!!!' 


\section{Amufement for ftarving Mechanics.}

FOR THE BENEFIT OF

\section{The TYTHE AND TAX CLUB.}

Shordy will be performed,

The COMICAL TRAGEDY of

L O N G F A C E S,

Prepared by a Herd of WOLVES in Sheep's Cloathing,

Tnder the Dircttion of a Gang of

\section{U T - T H R O A T S, \\ PLUNDERERS, and ASSASSINS,}

When they and their ve rudED Followers are a Third Time, by a Decree of

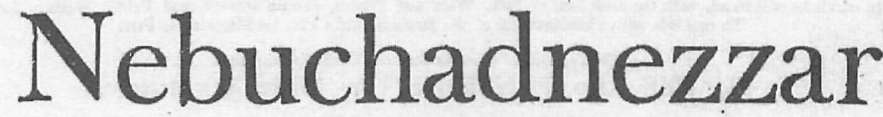

KI ING OF BAB $Y L O N$,

To call upon tbeir Gop

To blefs their ARMS and fanctify their CRIMES:

He being, when before called upon either Talking, or Purfuing, or on a Journey, or peradventure Sleeping $I t$ is expeeted they will cry out much louder than heretofore, and cut themfelves with knives and lancets after the manner of Baal's Priffts, 1 . Kings, c. 18.

The FRIENDS oF MAN I I D, Are defired at the fame time, to pray earasfly to the

GOD of ELIJA H

to continue his protedion and affitance to the Righteous in their own defence to " abate the pride, affuage "the malice, and confound the cevices," of the cruel and tyrannical Butchers of the human race, and to humble their iron hearts to fpeedy terms of PEACE and SUBMISSION.

\section{Hearken O ye Hypocrites!"}

of Is not this the faft that $I$ have chofen? to loofe the bands of wickednefs, to undo the heavy burdens, and to let the oppreffed go free, and that ye break every yoke? - Is it not to deal thy bread to the hungry, and that thou bring the puor that are calt out of thy houfe? when thou feeft the naked, that thou cover him, and that thou hide not thyfelf from thine awn fielb?" lfaial lviii, v. 6, 7.

$$
\text { WHICH OF THESE THINGS HAVE YE DONE? }
$$

$$
\text { A } N \text { D }
$$

WHICH OF THESE THINGS HAVE THE FRENCH NOT DONE?

Ye vile Hypocrites! - Ye infatuated Monfters! bow dare ye approach the Throne of Him whofe grand precept is Peace and govi-will is all $M: n$, (your hearts bemg filled with wickedne/s and deceit; and garments dyed with blood) to implore Divine affiftance for the deftruttion of thofe who have faithfully and effectually executed thefe facred commands? Ceafe then, ye impions vetches! hide your guilly heads, in your own confufion! Sue for PEACE, and crave Mercy from an offended Deity, left that vengeance overtake you, which

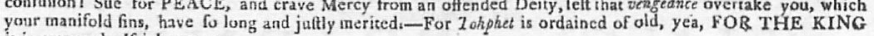
it is prepared, Ifaiah $\mathrm{x} \times \mathrm{x} .33$.

Ye Tyrants bend to Molloch's liarine,

With murd'rous Hands and Hearts of Itecl,

Wait, faft, and pray, till WRAIH DIVINE,

Well may ye tremble while each Throne,

Make your obdurate fpirits feel.

'The thund'ring arm of Heav'n will foon

Inflict the grand, decifive blow.

But dare not alk the PRINCE of PEACE,

Dare not the GOD of LOVE impiore;

To give your foul defigns fuccels,

And dreneh his earth in crimion gore.

Your puny efforts are in vain,

To keep the Human Race in thrall

GOD has efpous'd the Caufe of Men,

And both decree that you mult fall.

At the TREE of LIBERTY, No. 2, St. Ann's-court, Dean-ftreet, Sobo-fquare; where may be had, variety of cheap Patriotic. Publications.

Figure 8. 'Amusement for starving Mechanics' 
GRAND ORDER OF PROCESSION

AT THE FIRST FORMAL ENTRY OF

\title{
LOUIS XVII. Into His City of Paris.
}

\author{
April 1. (A. D. - - not yet pofitively determined)
}

Hatchet-ment, Crovwned with Laured, His Serene Highnefs, the Duke of BRUNSWrCK at their bend.

R O Y A L L E G I O N,

Cooks, Dancing Mafters, and Fidlers,-Court Buffoons ten a Brent.

The beautiful Animal, called a FAvourite, Male and Female. Demireps four and four; interfiperfed with PRINCES OF THE BLOOD, Dignififed Clergy, and Emistrant Nobieffe, - Drunken MONKS, finging Te Deam.-VOLUNTARY NUNS, conducted by their Fathers,

A Troop of MARRIED WOMEN, efcorted by ABBES;

thcir Hubbands at a refpetful diftance: "CIVIL SOCIETY" in a Wreath over their Heads.

An Opera Girl mounted on a Minister of State, a Priest at Top.

"S O C I A L O R D E R"

brayed by Mr. CAssrso, elegantly dreffed in a fuit of Fufain, with a beautiful Plume of Parrot Feachers. Emblems of Agriculture;

viz, a broken Plotgh drawa by one lean Cow, and an Afs.

Statue of Conmerce, liding her Face. Right Hon. Mr. WY nid Regna." The Cardinal Virtues comprifed in a fingle figure, fincly executed, though not after the an-

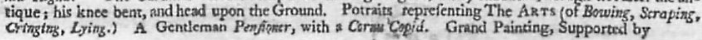

\section{TA X G A T HERER S,}

richly decorated t the fubject taken from life. viz. Want fhowering rags on Induffry. Beautiful Transparency, the BASTILE rifing from its ruins, furmounted by the words " Lettren de Cachet," in coloured lamps.

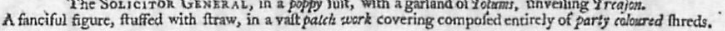

$$
\text { Grand Chorus of Spies, }
$$

Reciting with enthufasm, the moft wonderful difcoverics, and ingenious inventions of this or any other Cen-

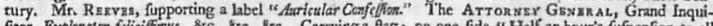

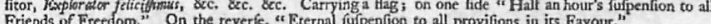
The Duke of PORTLAND, dreffed out with Ribbons, prochiming Stcarity.

The Earl of MassernuD, fhouting Indemnifications His Son, the young Auditor in his arms.
A T R I U P H A L C A R.

Drawn by Spanicls completely harneffed; Mr PITT, feated majeftically

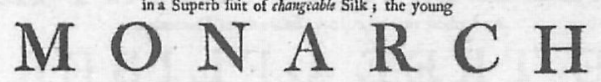

on his Knee 3 the Emprror and King of Prussta one on each hand, caresfing the great War Minitter; the Waggons of Britifh Coin;

An infription over each "Every one that afiketh, receiveth; and be that fecketh findect." Regiments, compofed of Troops just releafed from the Rod, or refcued from the Rope, forming the main body of the Britifl Army ;

preceeded by the Flower of ditto. - viz. A Company cumpoled entirely of Culonels in their teens; Mafter Jaskinson, fenoir in Cummand.

Ae the BRITISH TREE of LIBERTY, No. $4 \%$, Hkg-Market; may be had a variety of Patriotic Publications, inch ding the following. Liberty Songs. Precious Morfels ; on the bleffed Times we live in, Letter from Iolm Buli to the Decree for a Faft. Pittachios Exhibition 2 Parts, Muflapha's Adoration of the Sultan Pittander a Parts Mufapha's Difton's. Dundaffio's Erting Match. Exhilition of the Swinitith Mntititude. a Letter to a King. Letrer to a People.

The Return of Liberty. The Tree of Liberty, ssc. ssc.

Figure 9. 'Grand Order of Procession' 


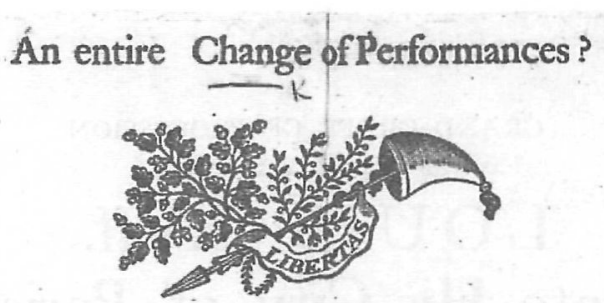

7 HE Public having heen for a long Scries of Years entertained at a Prodigious Expence, with the unrivall'd 1 Deceptions of PIrxacuro, and his Fellow Profefiors in the Black Arts; they are now inform'd that Fiction mutt give way to Truth, and Reality fupply the Place of Delufion! In cofequence of which,

\section{The Swinifh Multitude}

will difplay a Variety of Wonderful Performances, exhibiting friking Pròofs of their Wifdom, Strength, and Activity, having (to Accommodate the Tafte of the Mọbility of this Country), received a courfe of Lefions in the Firn Schools of Paris, - In the Firf place they will agreeably firprize the SpeClators with the various Manoevres of

\section{STORMING A TOW ER,}

which will be done without the Aid of Military Tactics, and unretarded by the regalar Operations of a Siege, yet performed with a Dignity, and compofure fuch as aever before was witnefsed in a HERD OF SWINE. N.B. This performance will be Peculiarly intereffing to ACQUTH'TED FELONS.

Secondly, they will with the utmoft Eafe, and Facility (to prove the exquifite refinement of their Tafte) metamorphose a

\section{PALACE INTTO A PIG-STYE,}

\section{TREASURY CHEST INTO A HOG TROUGH:}

After which the Audience will be amufed with a Scene reprefenting the infide of a Minifter of State's WORKSHOP, wherein will be exhibited a Brilliane Variety of Coscombs, and Coronets; Stars and Garters; Places and Penfions. The firft of thefe Baubles the Pags will actually hand from the Shelf, and turn it to the

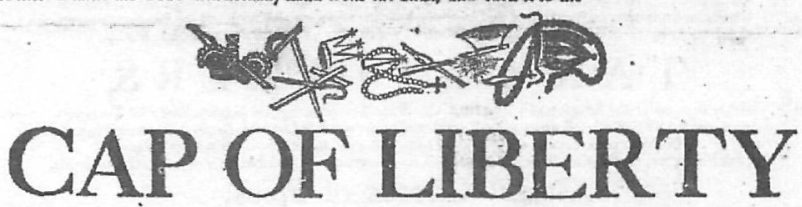

To the marvellous Satisfaction of all prefent- With the Garteri, they will in a mont ludicrous manner perform the Office of JACK KETCH on certain wicked, and notorious Malefactors, who it is already decreed thall be

REWARDED according to their WORKS. Thirdly, This inimitable Troog of Performers will moet Effectually

DEMOLISH A BASTILLE And plant on the ruined Bulwark of Despotism

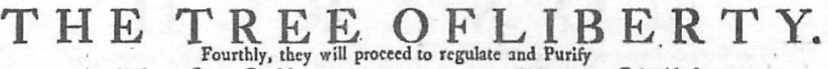

A Houfe of Ill-Fame, or, a Den of Thieves

(not a Hundred Miles from St. Stephen's___ ) contaiuing ample Materials, which after mature deliberation and a fair Trial (thoughnot a Nine Day's One), will befound inceorruptibe and fit for decorating and ornamenk'ing The LAMPIRONS in PARLIMENT STREE'T.

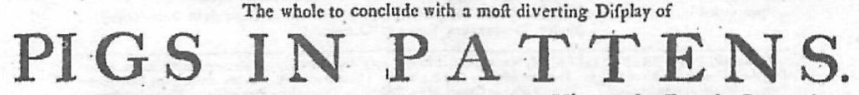
Vivant la People Soveraigne.

A Variety of other Performances are preparing, and will be announced to the Public in due Time. At the BRITISH TREE of LIBERTY, No 47 , Hay-Market may be had a varicty of Patriotic poblications, including the following. Liberty Songs.-Precious Morfals ; on the Bleffed Times we live in.--Letter from John Bull to the Popc,--Harlequin Stadtholder..-The

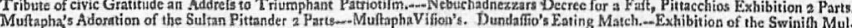
tifude. Lerter to 2 King. Letterto a People. Duke of York's New Mareh. Tho Genius of Liberty. Proclamation of Liberty, Equality and Fraternity. Rights of Swine. Thie Return of Liberty. The Tree ol Liberty, \&s, kc

Figure 10. 'An entire Change of Performances?' 


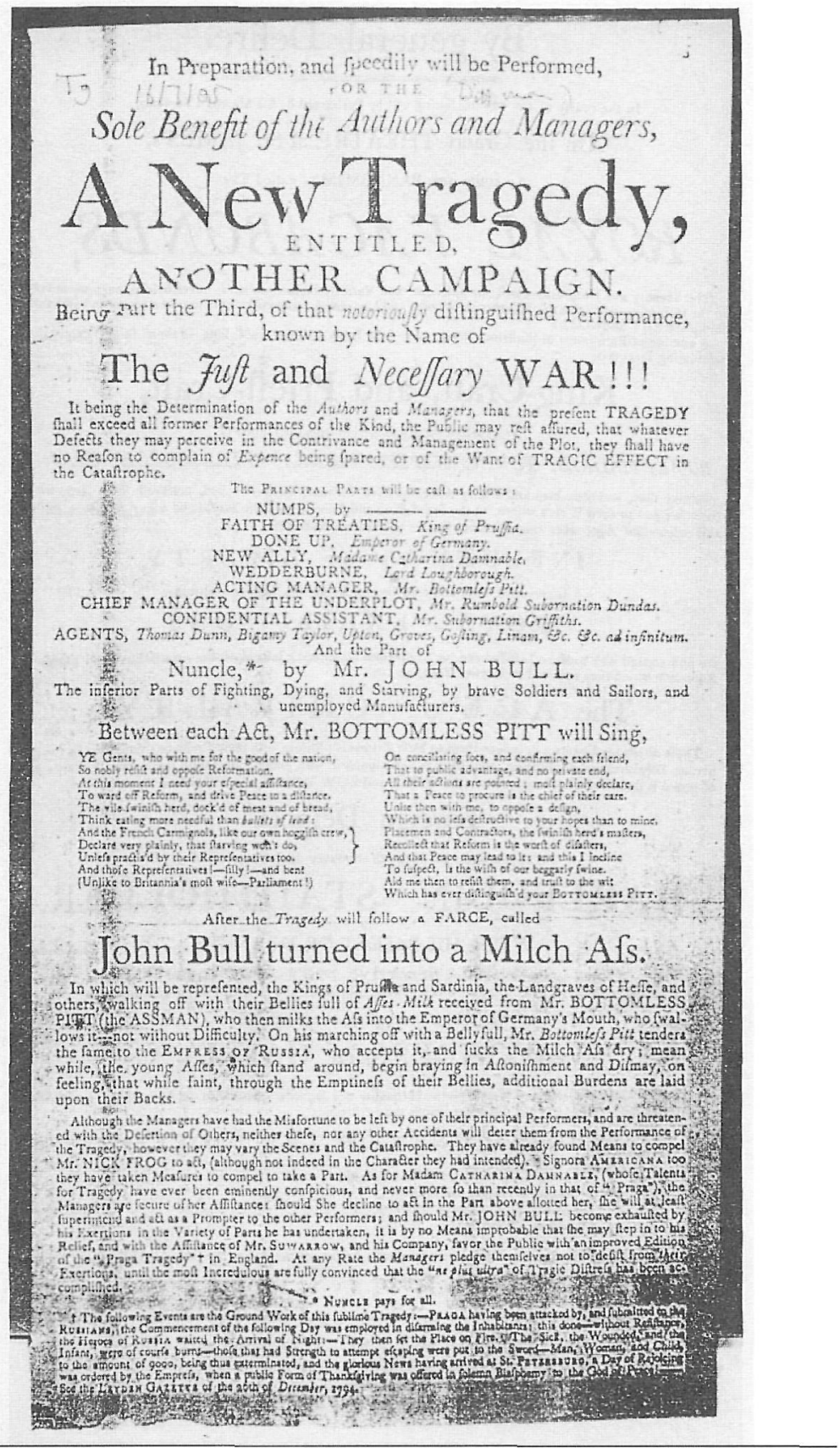

Figure 11. 'In Preparation, and speedily ...' 


\section{By general Defire.}

In the courfe of the enfuing Spring will be Performed by his Majelly's Servants,

On the Grand THEATRE at St. JAMES's, An entire new PANTOMIME, called The

\section{ROYAL VAGABONDS,}

The Scenery and Decorations, will, for Splendor, and Variety, be fuch as have never before been witneffed in the Univerfe-will ftrike the Vulgar with Wonder andAmazement; and raife Senfations of Rapture and Delight in the Univerfe-wilN in the GREAT and NOBLE,

in the GREAT and NOBLE, A number of Perfor
fafcinating Powers of

\section{King-Craft, and Prieft-Craft, \\ Are expetted thortly to Arrive from the Courts of}

ROME; MADRID; TURIN; NAPLES; VIENNA; PETERSBURGH, ङC. $3 c$.

Where they, and their high and mighty Anceftors have for many Centuries patt, pratifed their Arts, with Succefs equal to their Wideft wilhes, to the Satisfation and Content of their datiful and loving Subjetts. But in this degenerate $\mathrm{Age}$, when that infetious fpecies of Madnefs, called the

\section{INFLUENZA OF LIBERTY,}

is prevalent to an alarming Degree among the Swinith Multitude,

\section{ROYAL EXHIBITIONS}

are now treated with profane Indifference, or facrilegious Contempt; inflead of that extatic Love and profound Adoration which they received in Days of Yore, and in

\section{The A GE OF CHIVA L R Y.}

Thefe difaftrous Events will induce them to blefs Britannia's Shores with their Prefence; confiding in the generous Difpofition of Englifhmen, who have hitherto fparned with noble indignation their own Welfare; and efteemed it their higheft Glory to wear the YOKE and BOW DOWN, the HUMBLE SLAVES of

\section{Foreign Defpots.}

The Managers are happy to anhounce the fafe Arrival of

\section{HARLEQUIN STADTHOLDER,}

WITH HIS BASKET OF ORANGES

who will open the Entertainment with many DIVERT1NG TRICKS, which added to the fublime Exertions of the Performers above recited, will gain much popular Applaufe, and fet the WORLD a laughing I

The Whole will happily conclude with the

\section{WONDERS of GALLIA!}

Whercin the prefent inverfion of Nature; - the Inequality and Diforder effential to the Monarchial, and Ariftocratical Syftems of Tyranny, will difappear before the refiftlefs

\section{SOVEREIG NTY OF THE PEOPL E.}

The Cloud-capt Towers, the folemn Templet,

The gorgeous Palaces fhall be difolv'd,

And, like the bafelets Fabric of a Vifion,

Leave not a Wreck behind.

It ia the Order of the Managers that no Money be returned, or any of the vilgar Herd admitued behind the Scenes.

VIVANT REX ET REGINA.

Sold by R. LE.E, at the TrEx or Liserrr, No. a, St. Ann's-Court Dean,-ftreet Soho.

Where may be had, a Flaming Panegyric on the FAST-DAY, One Penny.-The Duke of Xork's New March One Penny, -And a variety of cheap Patriotic Publications.

Figure 12. 'By general Desire' 